\title{
In-situ stress orientations in the UK Southern North Sea: Regional trends, deviations and detachment of the post-Zechstein stress field
}

\author{
Williams, J.D.O ${ }^{1}{ }^{*}$, Fellgett, M.W. ${ }^{1}$, Kingdon, A. ${ }^{1}$ and Williamson, J.P. ${ }^{1}$ \\ ${ }^{1}$ British Geological Survey, Environmental Science Centre, Keyworth, Nottingham, NG12 5GG, UK \\ * Corresponding author Email: jdow@bgs.ac.uk Tel: 01159363100
}

\begin{abstract}
The orientation of the maximum horizontal compressive stress $\left(S_{H \max }\right)$ in the UK Southern North Sea has been determined using data derived from borehole breakout analysis of four-arm caliper logs. The results agree with existing stress models for NW Europe, confirming that horizontal stresses in the region have an approximately NW-SE orientation of $\mathrm{S}_{\mathrm{Hmax}}$. This is interpreted as being a result of plate boundary convergence. Local deviations in the horizontal stress orientations are observed spatially and also vertically within some wells. Some of these deviations are attributed to rotations of the stress field adjacent to faults or between different fault blocks. The data also suggest detachment of the stress regime in the post-Permian cover rocks, caused by the presence of a thick underlying Permian-aged evaporite sequence and associated halokinesis. Despite the generally low scoring of the stress measurements when compared with the quality ranking scheme proposed by the World Stress Map project, the consistent orientation of the stress trajectories suggests that these data are reliably indicative of regional stress orientations. Analyses of borehole resistivity image logs have been used to verify the calculated stress orientations in some wells. These image logs validate some measurements whilst highlighting a number of deficiencies in the use of four-arm caliper data to characterise borehole breakouts. From the available data it is difficult to unambiguously define the nature of variations from the mean stress orientations observed. Further analysis of image log data over greater depth intervals is therefore required in order to investigate
\end{abstract}


more fully the effects of stress rotations near faults and apparent stress detachment above saltcored anticlinal structures.

Keywords: In-situ stress, Southern North Sea, Borehole breakout, Halokinesis, stress detachment, salt-cored anticline 


\section{Introduction}

Knowledge of the in-situ stress field is required to understand the geomechanical response of subsurface systems to the extraction or injection of fluids. In the UK sector of the Southern North Sea (SNS), efforts to develop both conventional and unconventional reservoirs would benefit from an improved understanding of the stress affecting reservoirs and their overburden. Projects include further development of new or marginal exploration targets, as well as plans for seasonal subsurface gas storage (Havard \& French 2009). The prospect of using saline aquifers and depleted gas fields in the SNS for the sequestration of anthropogenic carbon dioxide (Holloway et al. 2006) also necessitates a greater understanding of the in-situ stress conditions. It is well documented that the injection of industrial quantities of carbon dioxide into reservoir rocks will result in increased pore fluid pressures within the connected pore volume (Bachu et al. 2007; NETL 2008; Noy et al. 2012). This will result in a range of geomechanically-induced deformation processes (Zoback \& Gorelick 2012; Verdon et al. 2013). Important considerations relevant to exploration and the utilisation of subsurface reservoirs include the integrity of reservoir sealing related to fracturing of cap-rocks and pressure-induced fault reactivation (Finkbeiner et al. 2001; Reynolds et al. 2003; Streit \& Hillis 2004). Additionally the production performance of fractured reservoirs, the optimisation of fracture stimulation works, wellbore stability and production/injection induced deformation is particularly relevant in certain operational circumstances (Maury et al. 1992; Hillis \& Nelson 2005; Hennings et al. 2012).

To address these issues in the SNS, a robust geomechanical model is required, the basic components of which will comprise knowledge of rock strength, pore pressure, existing fault properties and knowledge of the principal stress magnitudes and orientations (the in-situ stress field). Despite the long history of hydrocarbon development in the region, current compilations of stress orientation data (Klein \& Barr 1986; Cowgill et al. 1993; Heidbach et al. 2008) contain few direct measurements of the horizontal stress orientations in the SNS. An assessment of the horizontal stress orientations 
in the UK sector of the SNS is presented here, based on the analysis of borehole breakouts. The observations are discussed in terms of the prevailing crustal stresses and local perturbations resulting from faulting and potential stress detachment above salt-cored anticlines.

\section{Geological setting}

The main geological characteristics relevant to the analysis of in-situ stress are summarised below. More detailed accounts of the structure and stratigraphy of the area are given by Cameron et al. (1992), Doornenbal \& Stevenson (2010) and references therein. The area under consideration

(Figure 1) comprises the westernmost offshore extension of the Southern Permian Basin, a major foreland basin developed upon folded and tilted Carboniferous and older sediments deformed during the Variscan Orogeny (Underhill 2003). The Base Permian Unconformity truncates the uplifted Carboniferous strata as a result of fault reactivation, folding and tilting (Besly 1998). Following the deposition of aeolian, fluvial, sabkha and playa-lake sediments of the Rotliegend Group during the Early Permian, at least five marine transgressions resulted in the deposition of a cyclic carbonate-evaporite sequence ascribed to the Zechstein Group (Cameron et al. 1992; Taylor 1984). The Early Triassic saw a return to continental clastic deposition, and marine conditions have continued intermittently since the Late Triassic. Widespread uplift during the Middle-Late Jurassic resulted in much of the Jurassic and some older strata being removed beneath the Late Cimmerian Unconformity over much of the basin. Marine transgression during the Cretaceous resulted in the deposition of marine sediments above the unconformity, with a reduction of clastic sediment input leading to deposition of the Chalk Group during the Late Cretaceous. Upper Cretaceous, Tertiary and Quaternary sediments are thickest in the eastern part of the study area near the UK-Netherlands median line. Structural inversion during the Late Cretaceous resulted in contractional reactivation of existing deep-seated normal faults to the south of the Zechstein salt basin, and at least two later stages of structural inversion occurred as a result of Alpine events (Badley et al. 1989; Yielding et al. 2011). 


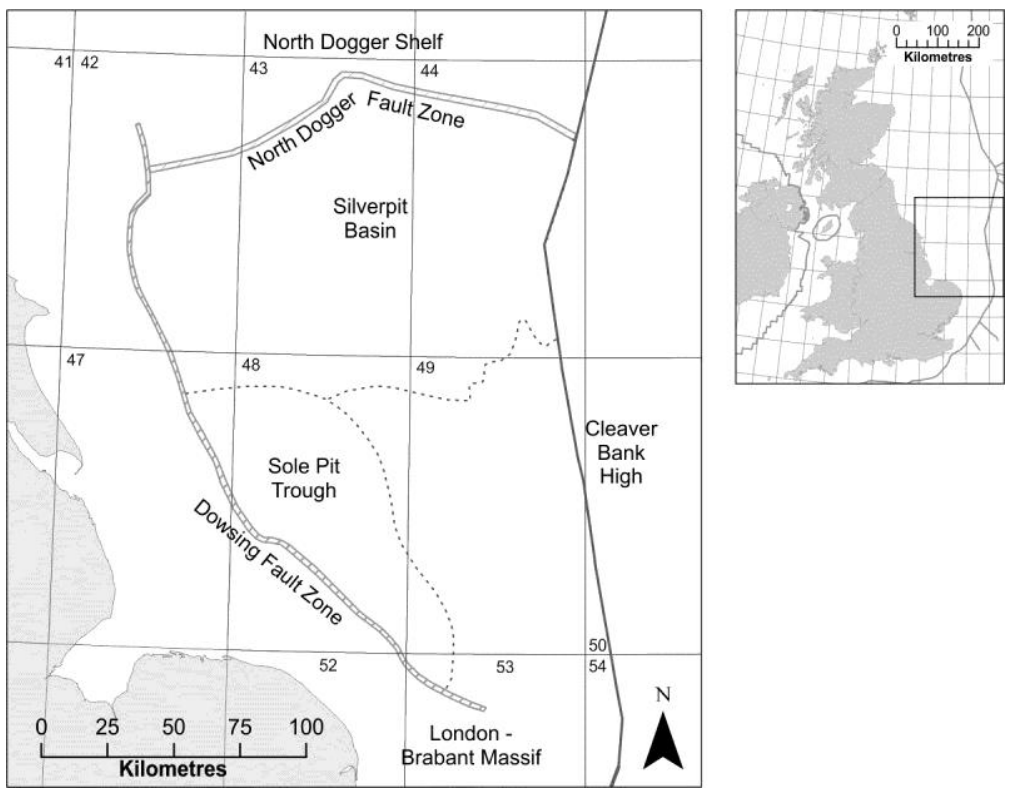

Figure 1 Location of the UK Southern North Sea and major structural features. The numbers refer to the UK Quadrant grid of the UK continental shelf.

The Zechstein evaporites are widely characterised by halokinesis which initiated during the latter parts of the Triassic and continued intermittently throughout the Mesozoic (Allen et al. 1994). A major later phase of halokinesis occurred during the Early-Mid Eocene, and continued progressively into the Oligocene (Underhill 2009). Salt movement within the Zechstein Group has resulted in markedly different structural configurations between the older strata and the Post-Zechstein Group sediments (Stewart \& Coward 1995).

\section{Borehole breakouts}

Analysis of borehole breakouts allows for the determination of the orientation of the two principal horizontal stresses in the subsurface, assuming the other principal stress to be vertical. Breakouts are caused by extensional or pure tensional failure of the wellbore wall (Zoback et al. 1985; Bell 1990), and are recorded as elliptical elongations in the otherwise circular borehole section. They occur when the concentration of stress exceeds the rock strength on opposite sides of a wellbore (Zoback et al. 2003). This process leads to rock failure through the development of intersecting conjugate shear planes. Plumb \& Hickman (1985) found that the long axes of borehole breakouts in 
vertical wells are oriented approximately parallel to the azimuth of the minimum horizontal stress $\left(S_{h \min }\right)$, with the orientation of the maximum horizontal stress $\left(S_{H \max }\right)$ perpendicular to the direction of borehole breakout. In contrast, the orientation of breakouts may also be influenced by material strength and/or elastic anisotropy in areas where there is low differential between the horizontal stresses, suggesting that rock fabric may dictate breakout orientation in some cases (Cuss et al. 2003).

Four-arm caliper logs from dipmeter surveys are commonly used to study the orientation of the insitu stresses. The primary aim of acquiring down-hole dipmeter surveys is to gather data pertaining to the dip and strike of sedimentary bedding. However the oriented and unprocessed logs can be used to interpret the presence and orientation of borehole breakouts. Where available, borehole imaging tools can also be used to identify borehole breakouts, and offer superior resolution and certainty. The dipmeter and pad-style resistivity image logging tools rotate as they are pulled up a well, with rotation ceasing if the opposing pair of caliper arms contact a bipolar enlargement of the borehole wall such as a breakout. The use of the caliper logs and their orientation data: azimuth of pad 1 (P1AZ), well deviation (DEVI), hole azimuth (HAZI) and the bearing of pad 1 relative to the high side of the borehole (RB), allow for the presence of breakouts to be distinguished from other forms of borehole enlargements such as washout intervals and key seating (Plumb \& Hickman 1985; Bell 1995). The orientation information contained in these curves also allows the azimuths of breakouts to be calculated. Figure 2 shows an example of four-arm dipmeter logs exhibiting borehole breakouts from the UK SNS. 


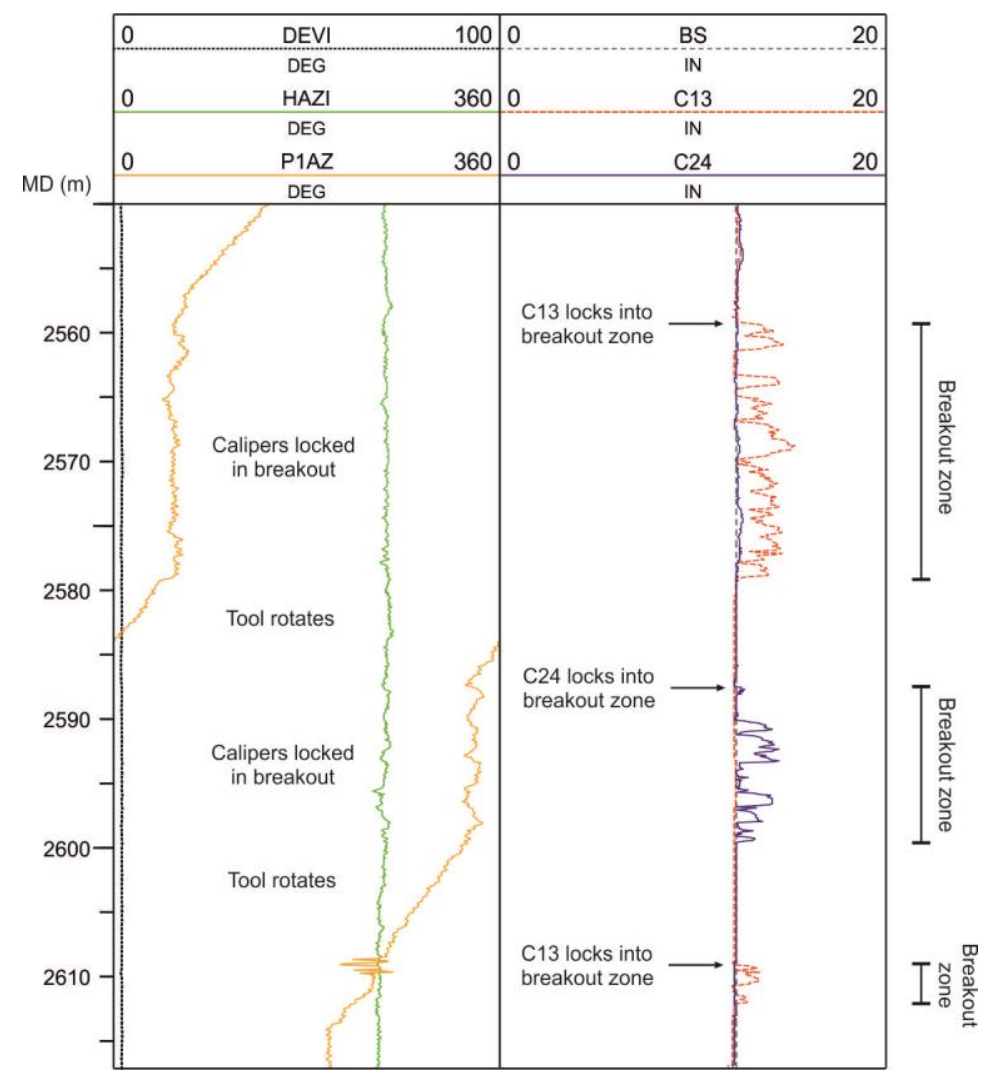

Figure 2 Example of borehole breakouts observed from four-arm caliper logs in well 49/28-12 (orientation of P1AZ where it ceases to rotate). The breakouts shown are oriented at $59^{\circ} \pm 5^{\circ}$, yielding an $\mathrm{S}_{\mathrm{H} \max }$ orientation of $149^{\circ} \pm 5^{\circ}$.

\section{Methodology}

Four-arm caliper data for 266 wells in the SNS were obtained from the Common Data Access (CDA) database (www.oilandgasdata.com). It was assumed that all orientation logs used were corrected for the local magnetic declination at the time of measurement (where recorded in the digital log headers, magnetic declination varied between $-7^{\circ}$ and $0^{\circ}$ ). Using criteria adapted from those recommended by the World Stress Map (WSM) Project (Sperner et al. 2003), wells with unsuitable data were eliminated, and breakouts were identified from observed elongations in the remaining boreholes. The criteria that were used are: 
a) A clear tool rotation is seen into and out of the zone of enlargement, with rotation ceasing within the enlargement zone itself. Visual inspection of log plots was used to eliminate breakout candidates that did not meet this criterion.

b) The smaller caliper reading should be close to the size of the drill bit, and the top and bottom of the breakout zone should be clearly identifiable.

c) The diameter of the larger caliper reading should exceed the lesser by no less than $10 \%$.

d) As key-seating can occur in deviated wells (Grollimund et al. 2001), breakouts were excluded if the orientation of the enlargement was within $+/-10 \%$ of the direction of borehole deviation, where the borehole deviation exceeded $5^{\circ}$.

e) Individual breakouts must be at least $0.3 \mathrm{~m}$ in length (Plumb \& Hickman 1985). This deviates from the WSM criteria, which stipulates $1 \mathrm{~m}$ as the minimum length for a single breakout zone. The lower value selected here is consistent with standard logging increments and pad sizes, and ensures that smaller features are included in the analysis, as the aim is to investigate stress orientations in the sedimentary basin and any deviations from regional trends. The inclusion of intervals less than $1 \mathrm{~m}$ in length was based on whether the individual elongations share a common orientation.

f) Borehole deviation should not exceed $10^{\circ}$ over the measured sections.

This final criterion is important because apparent breakout orientations in inclined wells may not always provide reliable indicators of the horizontal stress orientations (Mastin 1988); accordingly, data from 120 wells were excluded due to the logged sections being deviated by more than $10^{\circ}$. The remaining wells were analysed for borehole breakouts using criteria (a) to (e), with breakouts being identified in 68 wells.

The average orientation of $\mathrm{S}_{\mathrm{H} \max }$ (weighted by the number of $0.1 \mathrm{~m}$ measured intervals) and standard deviation of the measurements for each well were calculated using the circular statistics of Mardia (1972). A quality ranking scheme (Table 1) was applied to the measurements, with ranking criteria 
based on those in the WSM guidelines (Sperner et al. 2003). The WSM criteria have not been followed exactly because they are optimized for 1:1 000000 scale mapping of regional crustal stress orientation in basement rock and as such are a useful guide as to how to evaluate quality of potential breakouts, but are not specifically relevant to higher resolution mapping. In addition, it was found that insufficient breakouts would be identified to determine the stress orientations to the required level of detail if the WSM criteria were applied strictly, and therefore less restrictive breakout length criteria have been used in practice. This means that measurements of lower quality have not necessarily been excluded on the basis of quality ranking alone, and allows for a more detailed analysis of stress orientations and their variation.

The mean breakout orientations for each well averaged over the whole logged intervals are given in Appendix A, while the numbers of wells exhibiting breakouts in each category are shown in Table 2.

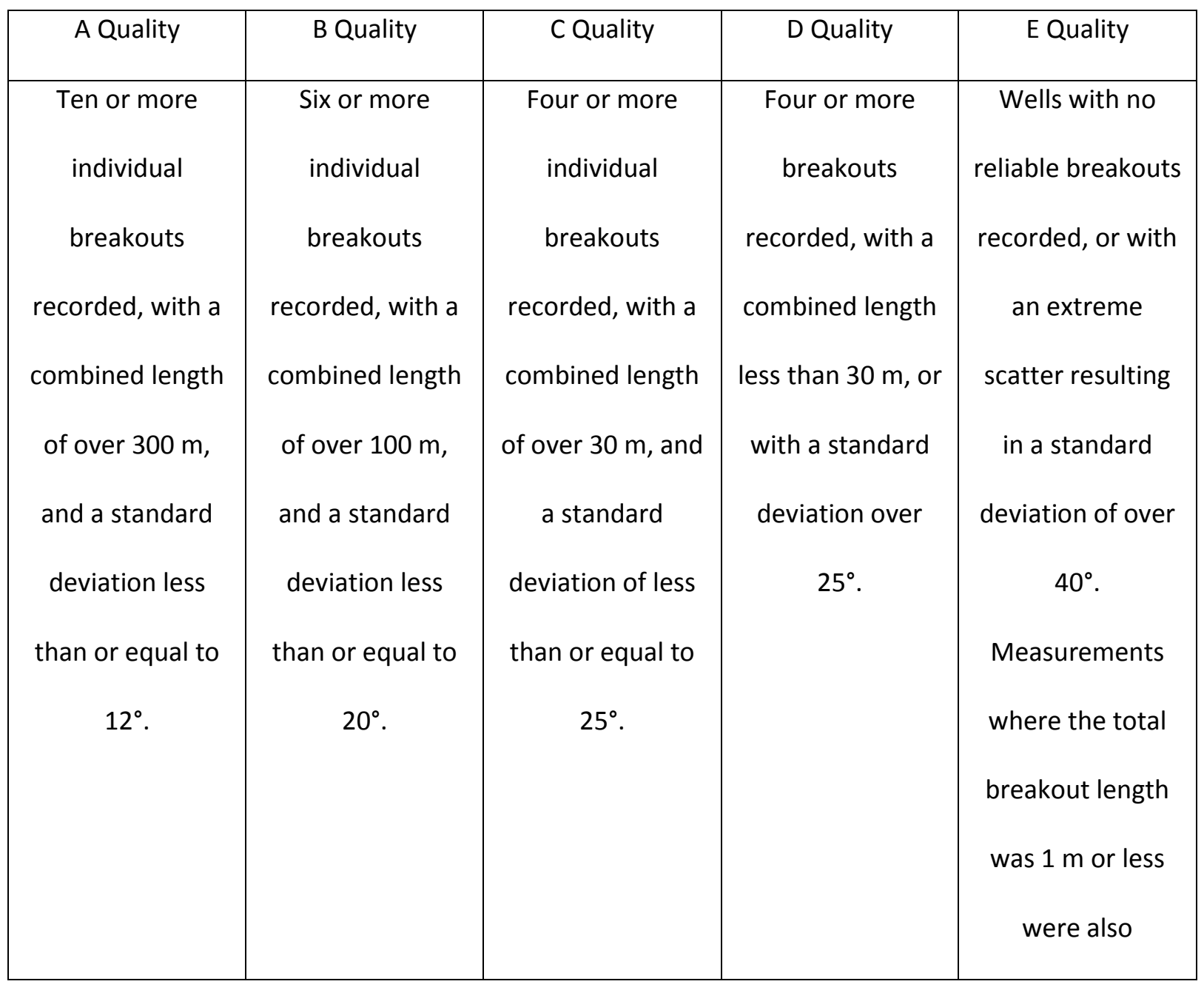




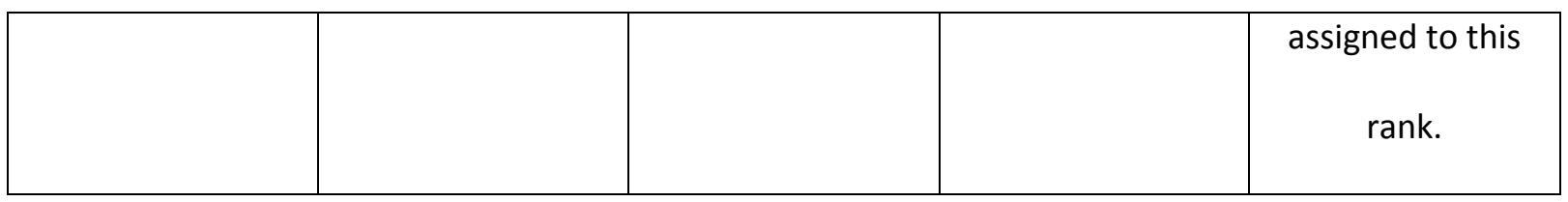

Table 1 Quality ranking scheme for stress orientations derived from borehole breakouts, adapted from Sperner et al. (2003).

\begin{tabular}{|l|c|c|c|c|c|}
\hline & A Quality & B Quality & C Quality & D Quality & E Quality \\
\hline Number of & 1 & 2 & 13 & 44 & 8 \\
wells & & & & & \\
\hline
\end{tabular}

Table 2 Number of wells exhibiting breakouts in each quality rank.

Table 2 shows that only 16 of the 68 stress orientation measurements derived from borehole breakouts can be classified as being of category A-C quality. These would be regarded as reliable indicators of $\mathrm{S}_{\mathrm{H} \max }$ by the WSM Project (Sperner et al. 2003; Heidbach et al. 2010) and are most likely to be indicative of regional tectonic stress patterns. Of the 44 category $D$ measurements, only five well measurements record standard deviations of over $25^{\circ}$ which constitutes the upper bound to category C. Most are limited by either the number of observed breakout zones or the total cumulative length of the breakouts. In the case of the category E measurements, three of the eight record high standard deviations $\left(>40^{\circ}\right)$, while the total breakout length of the other measurements is less than $1 \mathrm{~m}$. Yassir \& Zerwer (1997) have stated that the predominance of relatively weaker rocks and local stress variations can result in the downgrading of breakout measurement quality in sedimentary basins. The generally low-ranking breakouts presented here are nevertheless thought to demonstrate the regional stress signature. In some cases they also highlight locally constrained perturbations of the stress conditions in the UK SNS.

Of the 18 category C-D breakout measurements which showed a total combined breakout length exceeding $30 \mathrm{~m}$ (the requirement for category C), nine meet the standard deviation criteria for rank A and four met the criteria for category B. Only five of the 18 measurements were limited to either rank $C$ or $D$ on the basis of their standard deviation. Likewise, 37 of the measurements classified as 
category $\mathrm{D}$ record a standard deviation of less than $20^{\circ}$. These wells were prevented from being of a higher rank by the low number of individual breakout zones or short combined length of the measurements. This generally implies that although the individual breakout measurements classified as rank $D$ are of a reasonable quality, they simply do not meet the WSM length criteria. These measurements may serve to identify local stress orientations restricted to particular shorter intervals.

In order to investigate whether there is a degree of stratigraphic control on the orientation of $\mathrm{S}_{\mathrm{Hmax}}$ the data were also sorted stratigraphically (see Appendix B for summary of individual well data). The stratigraphic intervals identified include; the Cenozoic, Cretaceous, combined Jurassic and Triassic, Upper Permian (Zechstein Group), Lower Permian (Rotliegend Group), and the Carboniferous. In the event that a continuous zone of breakout with a uniform orientation crossed one of the stratigraphic boundaries, the breakout was assigned to the interval in which it predominantly occurred.

\begin{tabular}{|c|c|c|c|c|c|c|}
\hline & Number of & \multicolumn{5}{|c|}{ Number of wells showing breakout in each quality rank } \\
\hline & $\begin{array}{l}\text { wells with } \\
\text { breakout }\end{array}$ & A & B & C & D & $\mathrm{E}$ \\
\hline Cenozoic & 1 & - & - & - & 1 & - \\
\hline Cretaceous & 2 & - & 1 & - & 1 & - \\
\hline $\begin{array}{c}\text { Jurassic and } \\
\text { Triassic }\end{array}$ & 13 & - & 1 & 1 & 8 & 3 \\
\hline $\begin{array}{c}\text { Zechstein } \\
\text { Group }\end{array}$ & 11 & - & - & 2 & 8 & 1 \\
\hline $\begin{array}{c}\text { Rotliegend } \\
\text { Group }\end{array}$ & 19 & - & 1 & 4 & 11 & 3 \\
\hline Carboniferous & 45 & 1 & - & 8 & 31 & 5 \\
\hline Total & 91 & 1 & 3 & 15 & 60 & 12 \\
\hline
\end{tabular}


Table 3 Number of wells where borehole breakouts recorded within each stratigraphic interval and their quality rank. A total of 91 measurements were recorded from 68 individual wells. The mean stress orientations for each well, divided stratigraphically are given in Appendix B.

Table 3 highlights that very few measurements were available for the Cenozoic and Cretaceous intervals, while around a third of the measurements were recorded from the Carboniferous. This reflects the intervals over which dipmeter tools were run and is not an indication that the horizontal stresses in the younger intervals are necessarily isotropic. In fact, two of the best measurements (category B) taken from the same well show borehole breakouts in both the Lower Cretaceous Cromer Knoll Group and in the Jurassic intervals. Few dipmeter logs were available for analysis above the Jurassic as the majority of wells were only logged over deeper stratigraphic intervals, with cased sections above this level. This is a consequence of the economic importance of the Lower Permian and Carboniferous reservoirs. The propensity of the thick evaporite sequences to be washed-out during drilling limits the quality of dipmeter data over the Upper Permian Zechstein Group. Convincing borehole breakouts within the Zechstein were confined to brittle layers within the sequence.

It should also be noted that the separation of the measurements based on stratigraphy has some impact on the apparent quality of the measurements in wells where $\mathrm{S}_{\mathrm{H} \max }$ orientations were measured in more than one interval. This is a result of a decrease in the total combined length caused by the separation of breakouts within a well into stratigraphic groups. Conversely a comparison of the data in the appendices shows that the recorded standard deviations for some wells have been increased by this stratigraphic sorting. This is particularly apparent in the wells where markedly different $\mathrm{S}_{\operatorname{Hmax}}$ orientations are recorded across stratigraphic boundaries.

\section{Image log analysis}


Image logging provides high-resolution images of the borehole wall based on the resistivity or acoustic properties of the wellbore walls. Resistivity contrasts shown on borehole image logs allow features which are indicative of stress orientation such as breakouts and drilling induced tensile fractures (DIFs) to be categorised. Borehole breakouts are observed on resistivity image logs as poorly resolved parallel and conductive zones on opposite sides of the wellbore. In approximately vertical wells DIFs are typically observed as narrow vertical or sub-vertical features, and can only be identified on borehole image logs. They form parallel to the direction of $S_{H \max }$ when the stress concentration around the wellbore wall allows tensile failure to occur (Moos \& Zoback, 1990; Brudy \& Zoback 1999). DIFs therefore occur perpendicular to the direction of borehole breakout. Where breakouts and DIFs are observed together in a given well (as in well 49/14b-4, Figure 3a) they yield a reliable measurement of the direction of the principal horizontal stresses. Using imaging tools it is much easier to distinguish valid breakouts from drilling-induced artefacts or poor data quality compared to four-arm caliper data alone (Brudy \& Kjørholt 2001). However, the relative scarcity of available image log data in the UK SNS means that four-arm dipmeter data remain the primary source of information pertaining to the orientations of in-situ stresses. Formation Micro Scanner (FMS) and Formation Micro Imager (FMI) resistivity data (both Schlumberger trademarks) were available for six of the wells where breakouts were identified from four-arm caliper logs. This allowed for a comparison of the interpreted stress orientations and discussion of the validity of the stress orientations presented. Table 4 shows the results of the analysis, conducted using the WSM quality criteria for stress orientations derived from image logs (Sperner et al. 2003). The four-arm dipmeter data shown are the measurements taken from the entire logged intervals for each well, irrespective of stratigraphy (four-arm caliper data from Appendix A).

\begin{tabular}{|l|c|c|c|c|c|c|c|}
\hline Well Name & Tool & Number & Total & S $_{\text {Hax }}$ & Standard & Failure & Quality \\
of zones & length & orientation & deviation & Mode & \\
\hline $42 / 27 a-1$ & FMS & 8 & 24.5 & 159 & 14 & DIF & C
\end{tabular}




\begin{tabular}{|c|c|c|c|c|c|c|c|}
\hline & 4-arm & 6 & 4 & 155 & 13 & BO & D \\
\hline \multirow[t]{3}{*}{$44 / 21 b-11$} & FMS & 5 & 11 & 122 & 5 & DIF & $\mathrm{D}$ \\
\hline & FMS & 6 & 11 & 135 & 9 & BO & D \\
\hline & 4-arm & 11 & 50 & 24 & 27 & BO & D \\
\hline \multirow[t]{2}{*}{$48 / 02 b-3$} & FMI & 31 & 77.6 & 148 & 6 & BO & B \\
\hline & 4-arm & 7 & 37.5 & 39 & 11 & BO & C \\
\hline \multirow[t]{2}{*}{$49 / 02 a-5 Z$} & FMI & 32 & 24 & 144 & 8 & $\mathrm{BO}$ & $C$ \\
\hline & 4-arm & 1 & 1.1 & 140 & 2 & BO & D \\
\hline \multirow[t]{3}{*}{$49 / 14 b-4$} & FMI & 14 & 30.8 & 138 & 13 & DIF & $C$ \\
\hline & FMI & 11 & 8.8 & 127 & 7 & BO & D \\
\hline & 4-arm & 1 & 1.9 & 145 & 26 & BO & D \\
\hline \multirow[t]{3}{*}{$50 / 26 a-7$} & FMI & 2 & 16.5 & 146 & 8 & DIF & $\mathrm{D}$ \\
\hline & FMI & 2 & 2.8 & 159 & 3 & BO & D \\
\hline & 4-arm & 1 & 0.6 & 107 & 1 & BO & $E$ \\
\hline
\end{tabular}

Table 4 Comparison between $\mathrm{S}_{\mathrm{H} \max }$ orientations derived from breakouts and DIFs interpreted from image log data, with those derived from analysis of four-arm caliper logs. 

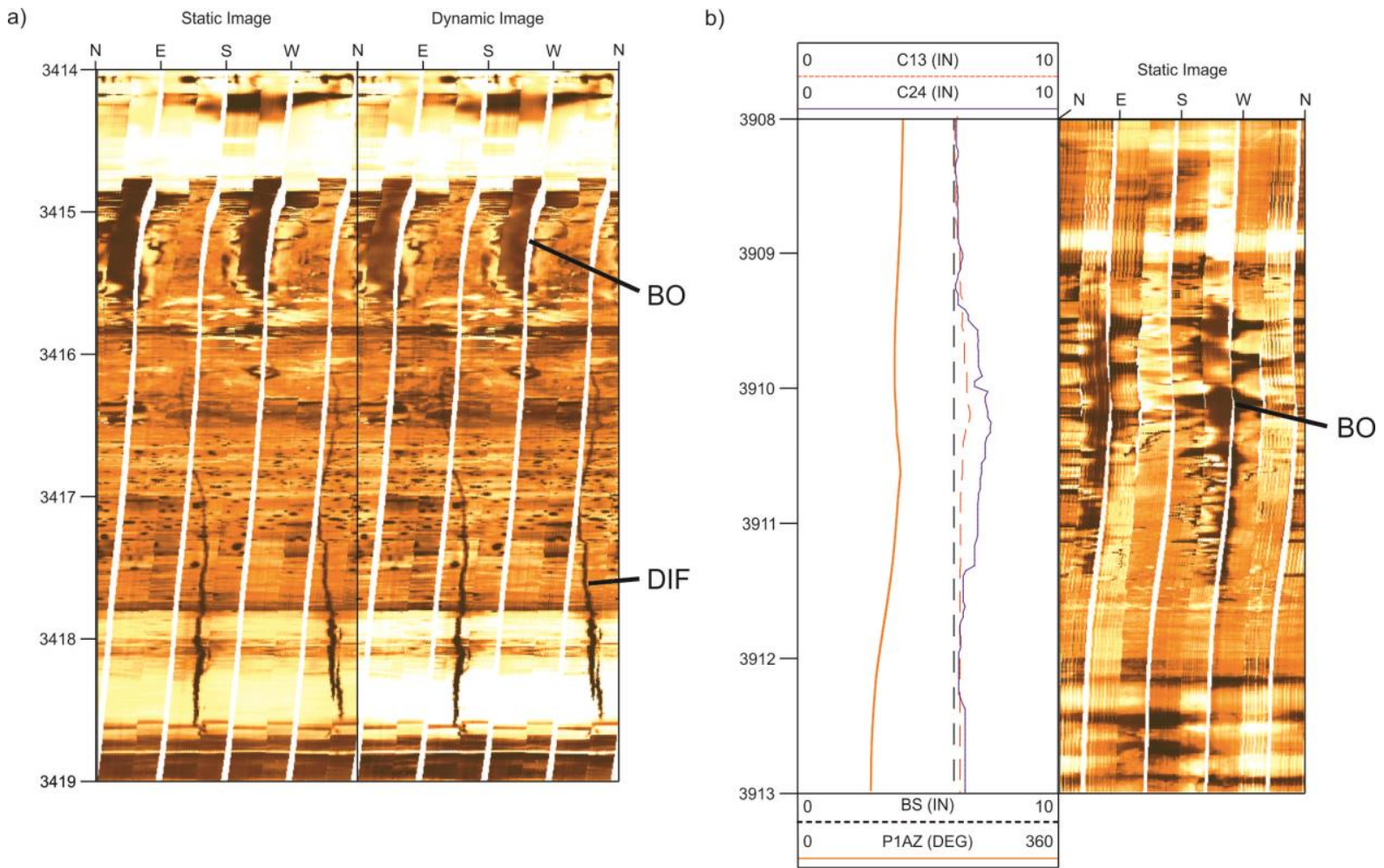

Figure 3 a) Example of breakouts (BO) and DIFs observed in well 49/14b-4. b) Example of consistent $\mathrm{S}_{\mathrm{H} \max }$ orientation between breakouts interpreted using four-arm caliper logs and borehole images in well 49/02a-5Z. Note that only a single breakout is observed using the four-arm caliper log (from around $3909.3 \mathrm{~m}$ depth), but many more breakouts of similar length and orientation to the example shown are seen at other depths on the image logs (Table 4).

The stress orientation measurements from image logs and four-arm caliper analysis in wells $42 / 27 a-$ 1 and 49/02a-5Z are very similar, indicating that in these wells the interpreted breakout orientations from the analysis of the four-arm calipers are valid. Some of the features interpreted using the fourarm calipers can clearly be seen on the image log data (Figure 3b), however many features seen in the borehole images are not identifiable from the caliper logs. The measurements derived from breakout analysis in well $49 / 14 b-4$ are also comparably consistent, but it is not possible to verify the interpreted breakout from the four-arm caliper analysis by the image logs because the two logs were run over different depth ranges. Image logs from well $49 / 14 b-4$ provide a strong case for a NW-SE orientation of $\mathrm{S}_{\mathrm{H} \max }$ with breakouts observed at $90^{\circ}$ to DIFs (Figure 3a). 
In contrast, markedly different $\mathrm{S}_{\mathrm{H} \max }$ orientations are seen between the image log and four-arm caliper tools in wells $44 / 21 b-11$ and $48 / 02 b-3$. The effect of key-seating at low deviations $\left(<5^{\circ}\right)$ was ruled-out as a mechanism for this. The four-arm caliper analysis for $44 / 21 \mathrm{~b}-11$ yields a NNE-SSE orientation. The breakouts interpreted from the four-arm dipmeter logs are derived from both the Rotliegend and Carboniferous intervals, while the image log analysis suggests the presence of breakouts in the Carboniferous interval only. The orientation of the breakouts affecting the Carboniferous interval derived from both the four-arm dipmeter and image log data is very consistent (Table 4 and Appendix B).

Analysis of the data from well $48 / 02 b-3$ shows that although there is good correlation between the depth ranges of observed breakouts in the image and four-arm caliper logs in this well, the computed orientations of $\mathrm{S}_{\mathrm{H} \max }$ are contradictory. It is thought that the orientation of the breakouts from the analysis of the image logs is superior to that interpreted from the four-arm caliper, and due to the improved clarity of the image logs they are more likely to provide a good indication of the $\mathrm{S}_{\mathrm{H} \max }$ direction.

In well $50 / 26 a-7$ the discrepancy between the measured orientations from the two techniques can be attributed to the fact that the four-arm caliper analysis yielded only a single breakout interval of poor quality, from within the Zechstein Werranhydrit Formation with a length less than $1 \mathrm{~m}$ (Category E). The image log section through this formation shows no sign of borehole breakout, with a feature-less resistivity image throughout the anhydrite-dominated interval.

Despite the conflicting breakout interpretations described above, there is generally good agreement in the orientation of $\mathrm{S}_{\mathrm{H} \max }$ derived from four-arm calipers and image logs, in particular where both sets of data show orientations consistent with regional trends. The comparison between measurements over the same intervals derived from the different datasets does highlight the inherent weakness of interpreting stress orientation from four-arm calipers alone. This suggests that some apparent localised deviations may be caused by misinterpretation of the four-arm caliper logs 
noted by Brudy \& Kjørholt (2001). It is noted however, that direct comparison is often complicated because image log data are not always available over the entire depth interval that has been logged using four-arm calipers.

\section{Results and Discussion}

In order to interpret the results, the orientations of $S_{H \max }$ across all intervals as derived from the analysis of four-arm caliper logs were plotted on a map of the UK SNS (Figure 4). The $\mathrm{S}_{\mathrm{Hmax}}$ orientations derived from image log analysis are also shown. It is apparent from the frequency plots that the measurements support a generally NW-SE orientation of $\mathrm{S}_{\mathrm{Hmax}}$. Nevertheless a considerable degree of variation is also observed, the variability being more pronounced in certain areas such as in UK Quadrant 44 (Figure 4). The number-weighted mean direction of $\mathrm{S}_{\mathrm{Hmax}}$ from measurements across all stratigraphic intervals is $148^{\circ} \pm 31^{\circ}$. The four highest quality measurements (Category $A$ and $\mathrm{B}$ ) in the stratigraphically constrained dataset all conform to the NW-SE regional $\mathrm{S}_{\mathrm{Hmax}}$ orientation, with $\mathrm{S}_{\mathrm{Hmax}}$ orientations of $140^{\circ}-157^{\circ}$. All but two of the quality $\mathrm{C}$ orientations are also oriented NW-SE.

In order to produce stress trajectories across the SNS from the observed orientations, the directional data were interpolated across the SNS using the methodology of Müller et al. (2003). This method derives a smoothing function from the data that is controlled by two parameters: a search radius $R$ and a parameter $\lambda$ that controls the influence of neighbouring measurements on the value at a point. Values for $R$ and $\lambda$ are subjectively chosen, although approximate ranges of values are suggested by Müller et al. (2003). Figure 5 shows two sets of stress trajectories in order to investigate the effect of using different values. It is seen that while using a $\lambda$ value of 0.5 results in trajectories aligned NW-SE, the use of higher values produces trajectories that are aligned in a more NNW-SSE orientation. The trajectories calculated using the lower $\lambda$ value produces a more 
satisfactory fit with the mean stress orientations. Where available, stress orientations derived from image log analysis were used in preference to those derived from four-arm calipers to produce the stress trajectories shown. The appearance of the stress trajectories suggests that $\mathrm{S}_{\mathrm{Hmax}}$ rotates from a predominantly NW-SE orientation in the southern part of the area, to a more NNW-SSE orientation farther north. Observations of $\mathrm{S}_{\mathrm{H} \max }$ shown in Figures $4 \& 5$ agree with the predominantly NW-SE orientation that is observed in the lithified basement rocks of NW Europe (Heidbach et al. 2008; Heidbach et al. 2010). Klein \& Barr (1986) and Gölke \& Coblentz (1996) suggest that this stress orientation reflects the configuration of plate boundaries and tectonic ridge-push effects.

The stress trajectories shown in Figure 5 also serve to highlight stress measurements that do not seem to conform to the regional stress patterns; for example, local stress variations significantly affect the stress trajectories in UK Quadrant 44. Some of these variations are likely due to the superposition of local factors that modify the orientation of $\mathrm{S}_{H \max }$ with respect to the regional stress field (Ask 1997; Gölke \& Brudy 1996; Fejerskov \& Lindholm 2000). Factors which might potentially affect $S_{H \max }$ orientation in the UK SNS include faulting, the presence of a thick Permian evaporite sequence (Zechstein Group) and the effects of halokinesis. 


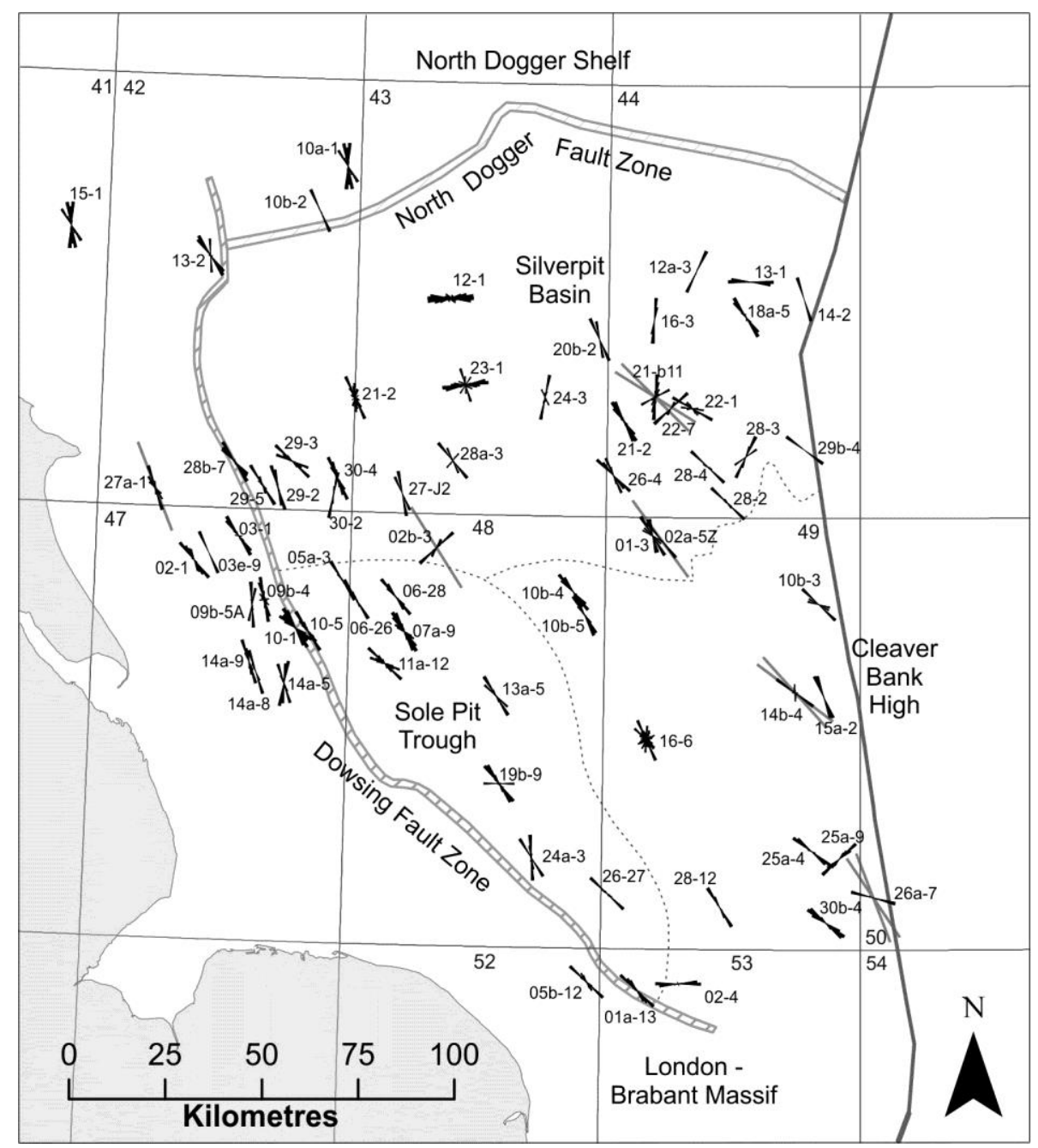

Figure 4 Frequency plots showing the orientation of $\mathrm{S}_{H \max }$ for all logged stratigraphic intervals across the UK SNS interpreted using borehole breakouts from analysis of four-arm caliper and resistivity image logs. Note that the rose diagrams are normalised to the number of measurements in each well. The result is that the relative frequencies of breakouts are not comparable across the different wells. Long grey lines represent $\mathrm{S}_{\mathrm{H} \max }$ directions interpreted from borehole image logs. 

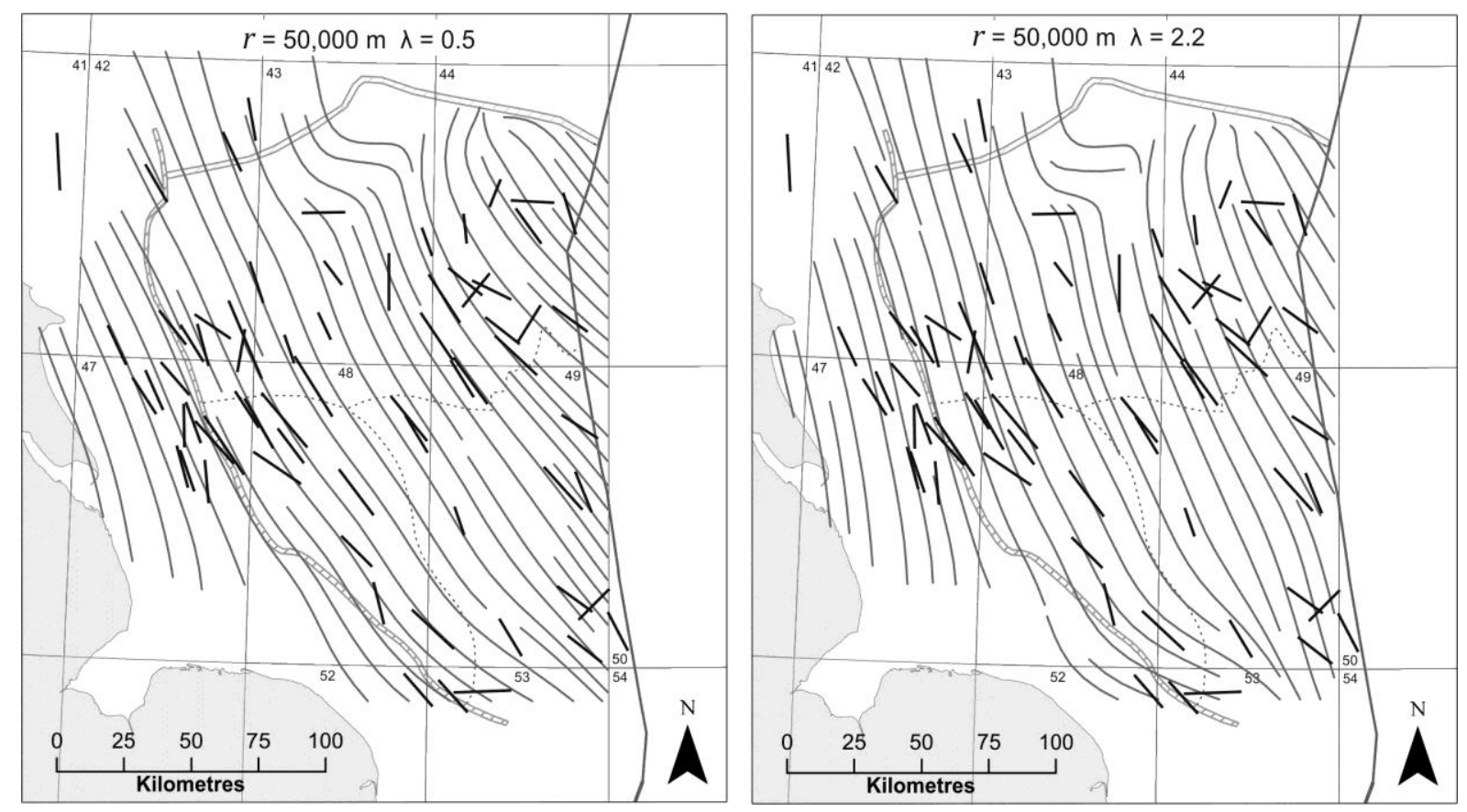

Figure 5 Mean stress orientations (longer lines denote higher quality measurements) and stress trajectories plotted using technique of Heidbach et al. (2010). The quality of the measurements is used here as a weighting function, and two different stress maps are given using a radius $(R)$ of $50,000 \mathrm{~m}$ and differing values of $\lambda$. Note the stress trajectories are intended to be an interpolation rather than an extrapolation, and are affected by edge effects particularly in the northern parts of UK Quadrants 43 and 44.

Figure 6 shows a series of rose diagrams displaying the aggregated orientations of $S_{H \max }$ from all wells over the different stratigraphic intervals. The general NW-SE trend is apparent from the majority of the rose diagrams though there is clearly some deviation from this. The Cenozoic rose is drawn from measurements taken in a single well (44/13-1). This is a category $D$ measurement showing a localised deviation from the overall trend. It is also supported by a category $E$ measurement from the Jurassic-Triassic interval in the same well with a very similar $\mathrm{S}_{\mathrm{Hmax}}$ orientation. The Cretaceous rose diagram is dominated by category B measurements which align NW-SE. The short perpendicular bin is a single Category D measurement in well 49/25a-9. The Jurassic-Triassic rose diagram shows considerably more variation with a standard deviation of $\pm 43^{\circ}$. 
The NW-SE orientation is dominant, but a roughly W-E trend is also seen arising from the markedly different $S_{H \max }$ orientations in wells $43 / 12-1$ and $44 / 13-1$. Variable stress orientations are seen within the Carboniferous interval in well $43 / 23-1$. While this gives the appearance of an E-W trend in the orientation of $S_{H \max }$ in this region due to its proximity to $43 / 12-1$ (Figure 4 ), it is noted that Figure 4 displays the stress orientations across all stratigraphic levels. Stress orientations differ between the Jurassic-Triassic and the Carboniferous intervals in well 43/12-1 (Appendix B), while there are clear rotations in the orientation of $S_{H \max }$ within the Carboniferous interval of $43 / 23-1$, perhaps indicating that the observed orientations are caused by local factors in each of the wells. The Zechstein rose shows the most variation in the azimuth of $S_{H \max }$ possibly due to poor data quality distorted by washout of halite-rich layers. This variation may also be due to the effects of halokinesis and subsequent deformation which causes rotation and rafting of certain horizons. Both the Rotliegend and Carboniferous roses clearly show that in these strata the azimuth of $\mathrm{S}_{\mathrm{Hmax}}$ is dominantly oriented NW-SE, reflecting the regional tectonic stress field. Where breakouts were recorded in both Carboniferous and Rotliegend intervals within a single well there is generally a very good agreement between the measurements (Appendix B).

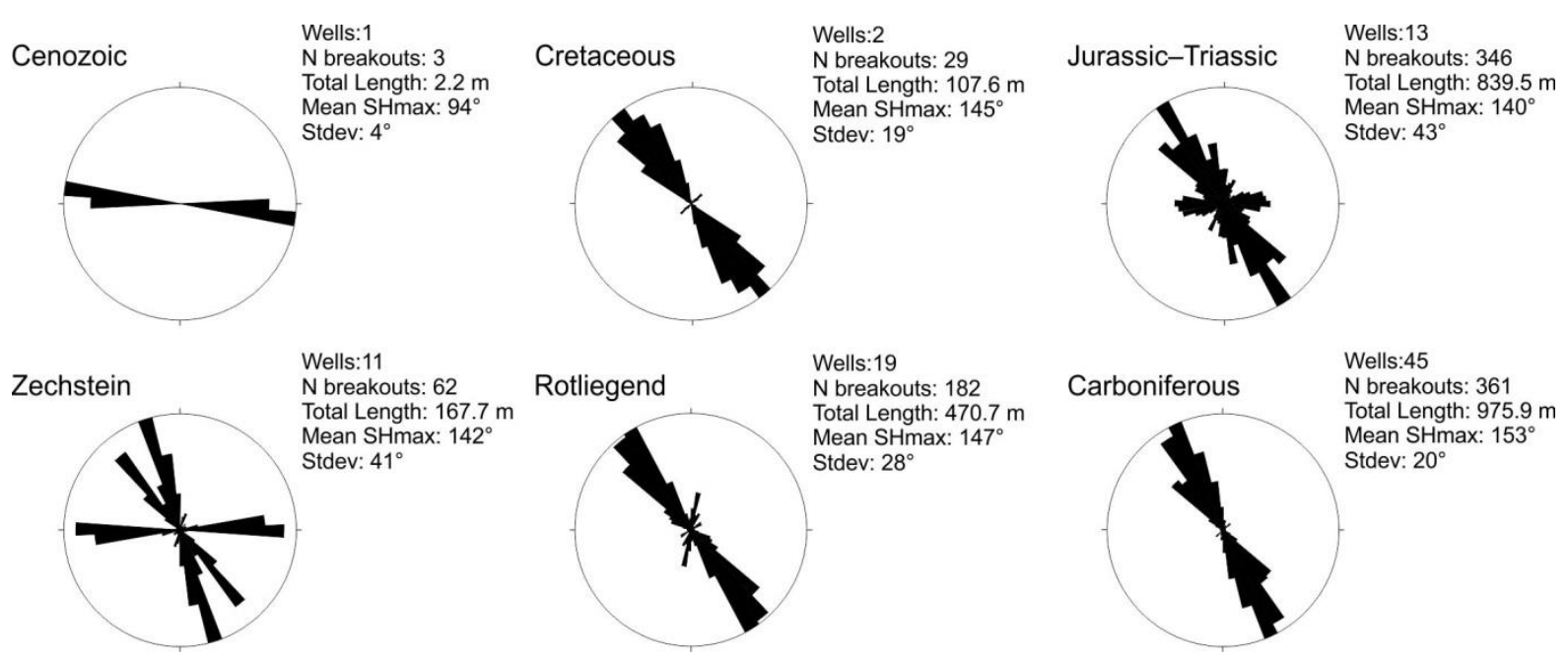

Figure 6 Rose diagrams of $S_{H \max }$ orientations derived from borehole breakout analysis in different stratigraphic regions. Note that each individual diagram has been normalised by the number of data 
points, so the length of the bins does not reflect the relative frequency of breakouts across stratigraphic boundaries.

\subsection{Stress rotations adjacent to faults}

Cowgill et al. (1993) describe the refracting influence of the Dowsing Fault Zone on the stress orientations in its vicinity. It is unclear from the data presented here whether faults associated with this fault zone are responsible for deflecting the stress orientations. It is however interesting to note that the observed $\mathrm{S}_{\mathrm{H} \max }$ directions do seem to be oriented parallel to the strike of the Dowsing Fault Zone along its length (Figures $4 \& 5$ ). Yale (2003) showed that $S_{H \max }$ orientations may be markedly different within adjacent fault compartments in hydrocarbon fields and illustrated this using a case study from the UK SNS. Decoupling of the stress field from regional trends adjacent to faults may result in part from fault compartmentalisation. This would allow for significant variations in stress orientation and pore pressure conditions between different fault blocks, even in areas with high differential stress (Yale 2003). The age and tectonic history of a given fault may also influence its ability to perturb or concentrate the local stress conditions; with active faulting more likely to be capable of perturbing local stress conditions (Barton \& Zoback 1994). Figure 7 supports the notion that the stress field may be rotated in some wells at levels below the Zechstein in the SNS, with the orientation of $\mathrm{S}_{\mathrm{H} \max }$ in some wells being deflected by stress perturbations related to faults. Wells $44 / 21 b-11$ (in the Rotliegend only), 44/22-7 and 44/28-3 all show $\mathrm{S}_{\mathrm{H} \max }$ orientations orthogonal to the strike of faults, whereas the other measurements all suggest $S_{H \max }$ orientations sub-parallel to faults. This suggests that some fault segments may be perturbing or compartmentalising the stress state to some degree while others are not having an effect. 

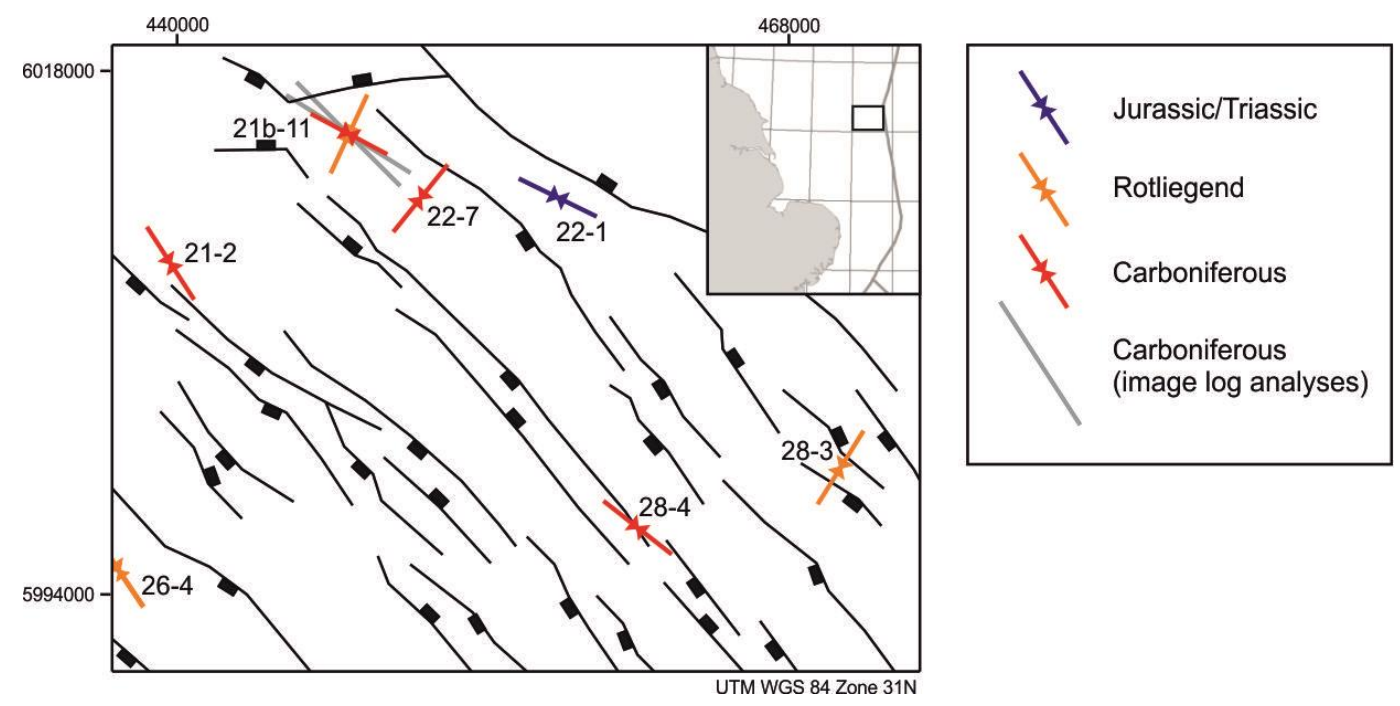

Figure 7 Possible deviations of $\mathrm{S}_{\mathrm{Hmin}}$ orientation associated with sub-salt faulting in part of UK Quadrant 44. Faults shown are at top Rotliegend level while the mean stress indicators shown are for various stratigraphic intervals (Appendix B). Note that the measurement in well 44/22-1 is taken at a shallower level not affected by these faults.

\subsection{Stress detachment above evaporites}

At least some of the variation in $\mathrm{S}_{\mathrm{Hmax}}$ orientations previously recorded within the sedimentary sequence in nearby regions has been attributed to stress detachment. This is associated with the presence of the Permian-aged Zechstein Group (Ask 1997; Fejerskov \& Lindholm 2000; Hillis \& Nelson 2005; Williams et al. 2014), which comprises a thick evaporite sequence. Halokinesis has occurred in the centre of the UK SNS, with Cenozoic halokinesis particularly in the Silverpit Basin (Figure 1) resulting in folding of the post-Zechstein cover rocks into a series of anticlinal ridges and associated synclines (Griffiths et al. 1995; Stewart \& Coward 1995; Underhill 2009). Structural configurations differ greatly in the post-Zechstein cover where the structure is dominated by the effects of salt movement, to those seen in the lower parts of the Permian and older strata (Figure 8). Stress detachments and anomalies associated with thick salt bodies and diapiric structures have been recorded elsewhere in diverse regions such as: the Nile Delta (Tingay et al. 2011), the Jura Mountains of Switzerland (Becker et al. 1987), and in the Gulf of Mexico (Yassir \& Zerwer 1997). 
Stress measurements suggest that a normal faulting stress regime is prevalent over the salt-induced anticlines in the Central North Sea area (Zoback \& Zinke 2002). This suggests that the stress regime differs from the dominantly strike-slip state of stress observed in adjacent areas in the onshore part of the UK (Evans \& Brereton 1990; Baptie 2010), and which is also thought to be prevalent in the basement rocks beneath the UK SNS.

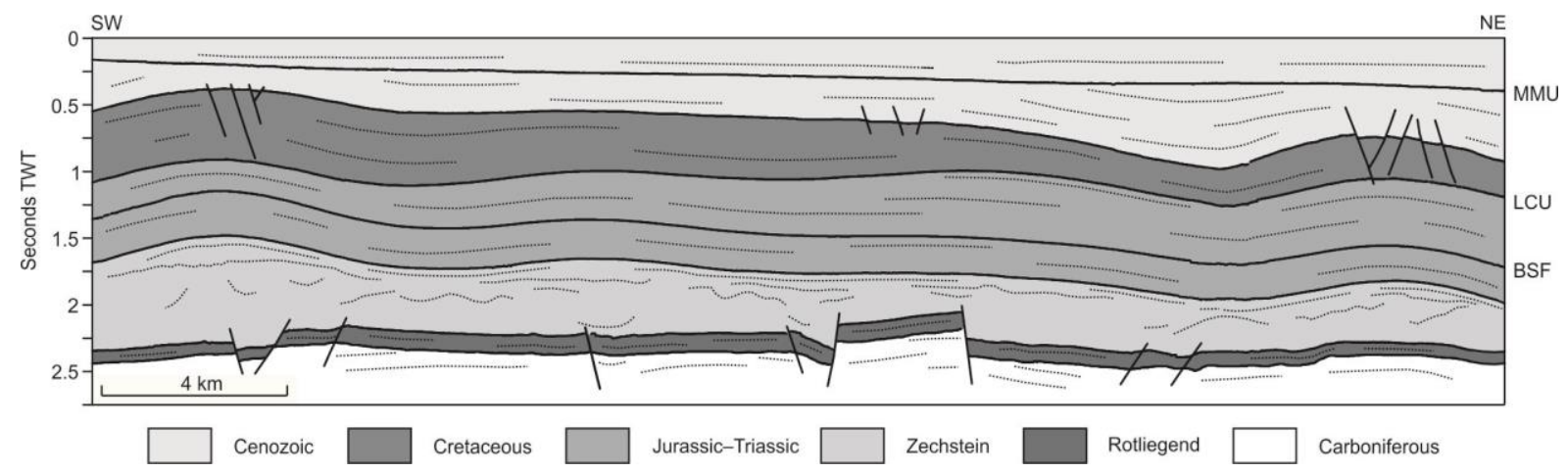

Figure 8 Representative line drawing across part of UK Quadrant 44 showing main stratigraphic and structural domains in two-way travel time (TWT). The Mid-Miocene (MMU) and Late Cimmerian (LCU) unconformities are marked along with the top of the Bunter Sandstone Formation (BSF).

Williams et al. (2014) postulated that $S_{H \max }$ measurements in the Jurassic-Triassic interval of well 43/12-1 may be related to stress detachment above the Zechstein evaporites, as they differ greatly from those recorded beneath the evaporitic sequence (Figure 9). The orientations of $S_{H \max }$ in the post-Zechstein are oriented roughly $\mathrm{W}-\mathrm{E}$, coincident with the long-axis of a salt-cored pericline into which the well was drilled, and parallel to the orientation of crestal extensional faults (Williams et al. 2014). Teufel (1991) reported variable $S_{\mathrm{Hmax}}$ orientations around a similar structure in the Norwegian sector of the North Sea where a normal faulting stress regime prevails. A similar effect is observed in experimental analogue models for dome formation (Withjack \& Scheiner 1982; Yamada et al. 2005), suggesting that the contemporary in-situ stresses might be affected by the salt-induced structure. The $S_{H \max }$ orientations derived for the post-Zechstein cover in all wells are shown by Figure 10. Keyseating is ruled-out as a possible mechanism for the observed borehole elongations as the 
azimuth of the features do not correspond with the direction of borehole deviation. In addition to $43 / 12-1$ there are two other wells (44/13-1 and 49/25a-9) where breakouts observed in the postZechstein cover do not conform to the NNW-SSE orientation of $S_{H \max }$ (Figure 10). Category $D$ measurements in these wells suggest anomalous mean $\mathrm{S}_{\mathrm{Hmax}}$ orientations within the area affected by halokinesis, while $\mathrm{S}_{\mathrm{H} \max }$ is oriented closer to the NW-SE trend in wells outside this area. It should be noted that the Zechstein sequence in well $49 / 25 a-9$ is relatively thin and consists largely of anhydrite rather than halite. The major evaporitic formations are absent in this well, perhaps as a result of faulting, salt withdrawal, or erosion prior to deposition of the overlying Triassic sediments. As a result, the factors controlling the observed stress orientations in this well remain unclear. A significant spread in $S_{H \max }$ orientation is also seen in the post-Zechstein succession of well 49/16-6 (standard deviation $\pm 48^{\circ}$ ). Well $49 / 16-6$ is situated within the area affected by halokinesis and is underlain by thick evaporites which may explain the large standard deviation. Combining breakouts from the Rotliegend and Carboniferous intervals from this same well gives a category $\mathrm{C}$ measurement with a mean orientation of $134^{\circ} \pm 10^{\circ}$. This shows that stress orientations beneath the Zechstein evaporites conform to the trends associated with regional tectonic effects. Nevertheless it remains uncertain whether the presence of thick halite bodies in the Zechstein Group over much of the UK SNS affects the in-situ stress state of overlying strata. 


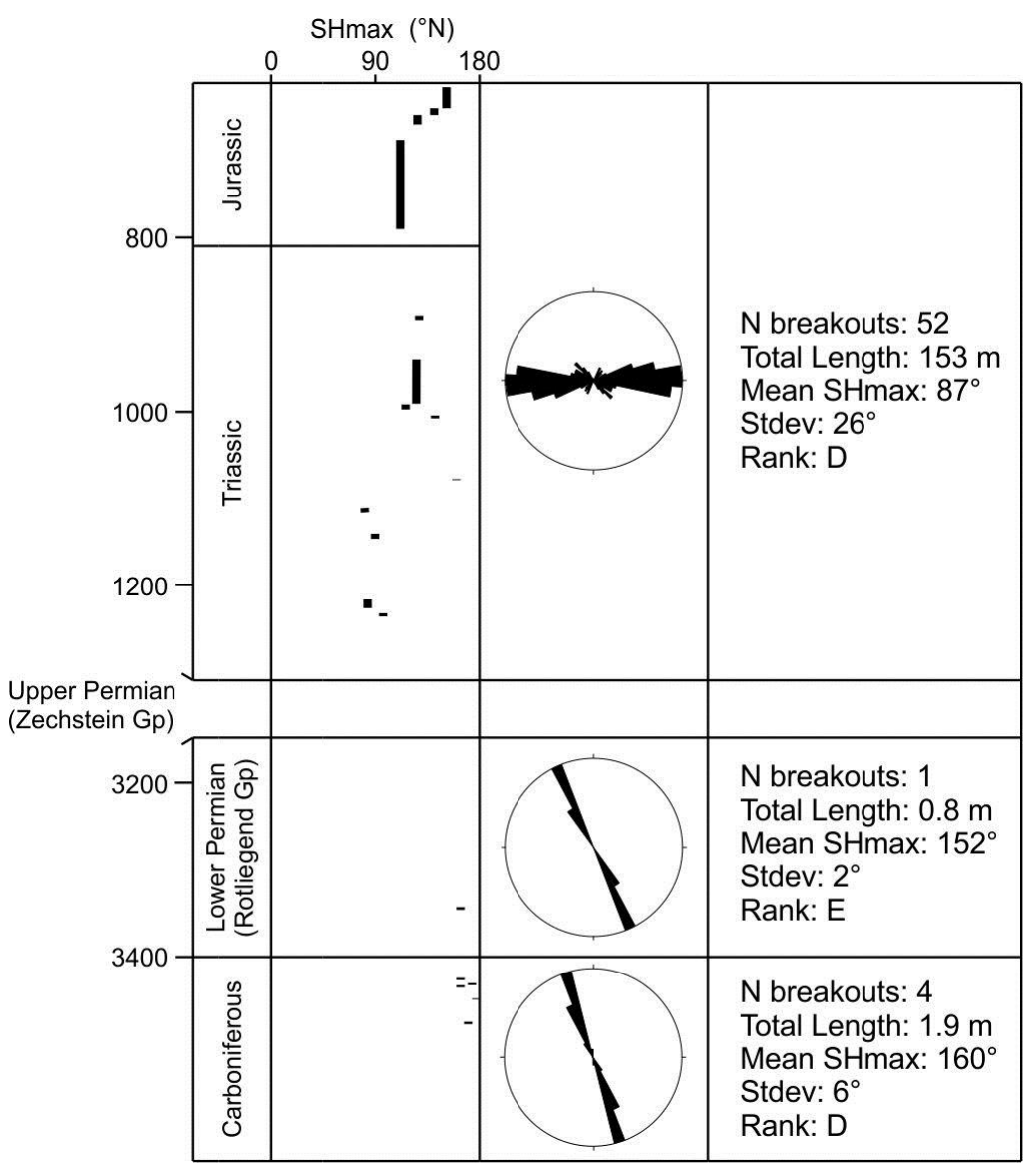

Figure $9 S_{H \max }$ orientation data from well 43/12-1, showing a possible stress detachment between the pre and post salt successions. The log track shows the depth ranges and azimuths of calculated $\mathrm{S}_{\mathrm{H} \max }$ orientations in the well. 


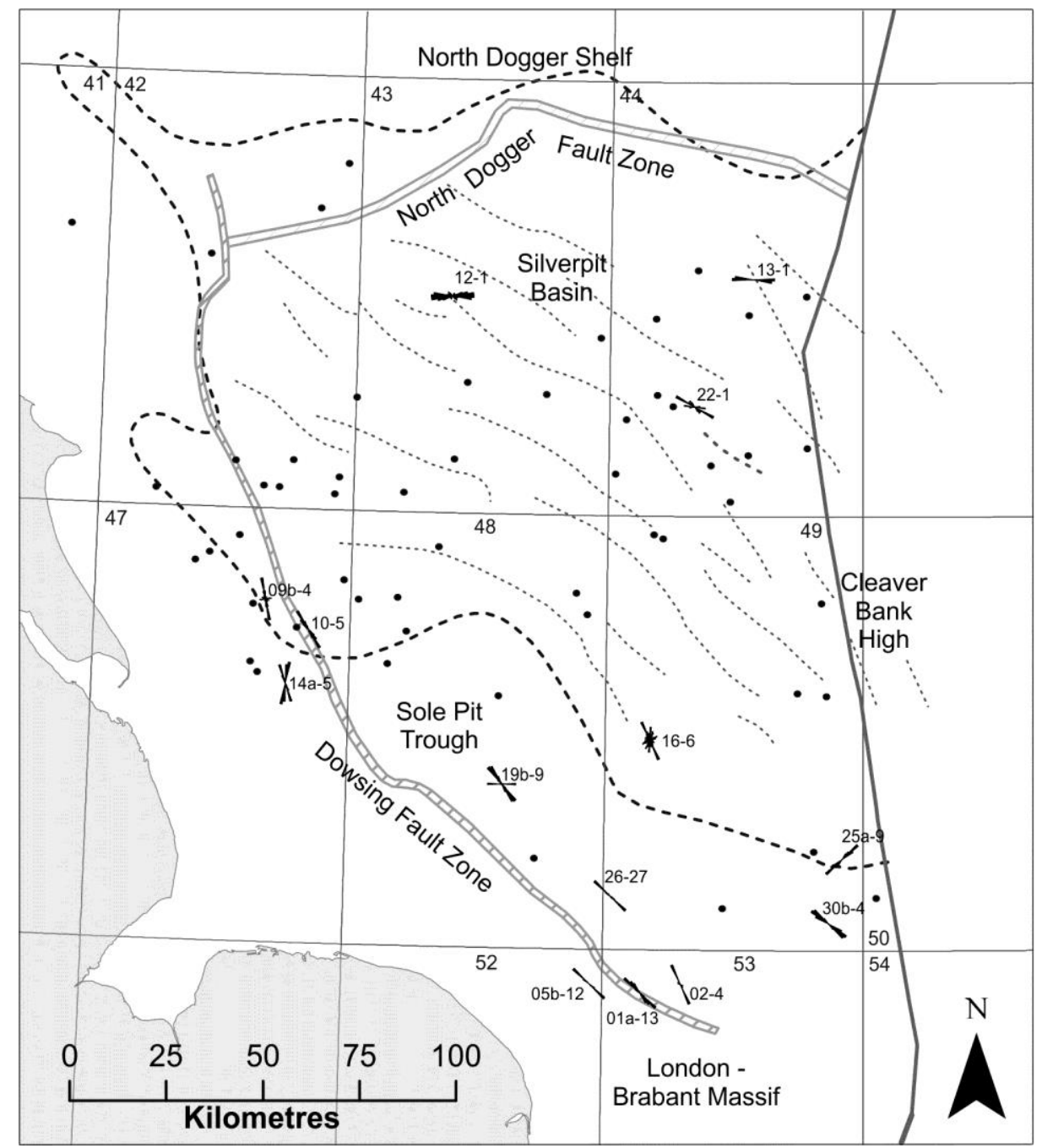

Figure 10 Post-Zechstein $\mathrm{S}_{\mathrm{H} \max }$ orientations displayed as frequency plots by well. The thick dashed line marks the area of Zechstein salt diapirism after Taylor (1984), while the grey dotted lines represent the approximate location of major salt-induced fold axes in the post-Zechstein cover after Wall et al. (2009).

\section{Conclusions}

The orientation of $\mathrm{S}_{\mathrm{H} \max }$ has been determined from the analysis of borehole breakouts from four-arm caliper dipmeter logs in 68 wells in the UK SNS. The data confirm that the region is affected by generally NW-SE maximum horizontal stresses, interpreted to result from the configuration of tectonic plate boundaries, as reported by previous authors. Superimposed upon this regional stress 
orientation are variations in horizontal stress orientations that are caused by local factors. These may include faulting and the presence of a thick evaporite sequence of Permian age exacerbated by salt pillowing and halokinesis. Application of the WSM quality ranking criteria would classify many of these measurements as low quality; however the calculated mean stress orientations and stress trajectories are consistent with current models attributing the orientation of stress to ridge-push forces. For those wells where the orientation of $S_{H \max }$ differs from this regional trend, it is difficult to unambiguously attribute this to controlling factors, but it is thought that faulting and compartmentalisation may play a role, and that detachment of the stress field caused by the presence of thick salt layers provide likely mechanisms. Where available, borehole image logs have been used to check the measurements for a subset of the data and in all cases they support the notion of a generally NW-SE regional stress orientation. The analysis of the image log data is limited by the availability of data both spatially and in restricted depth windows and so does not cover an appreciable coverage in terms of stratigraphy. In particular, no image log data is available in the post-Permian cover rocks. The image log analysis cannot therefore support the notion of stress detachment above salt-cored anticlines, although this is suggested by the analysis of four-arm caliper logs. It is surmised that most of the observed deviations are caused by stress perturbations or detachment, while some may be artefacts associated with the limitations of analysing stress orientation solely from four-arm caliper logs. Further data and analysis utilising borehole image logs are required in order to determine whether the stress field is effectively and consistently de-coupled from the prevailing basement stresses by the Zechstein Group evaporites.

\section{Acknowledgements}

Dr Sam Holloway is thanked for his insights and useful discussions during the study. This publication has been produced with support from the BIGCCS Centre, performed under the Norwegian research 
program Centres for Environment-friendly Energy Research (FME). This paper is published with the permission of the Executive Director, British Geological Survey (NERC).

\section{References}

Allen, M.R., Griffiths, P.A., Craig, J., Fitches, W.R., Whittington, R.J. 1994. Halokinetic initiation of Mesozoic tectonics in the southern North Sea: a regional model. Geological Magazine, 131, (94), $559-561$.

Ask, M.V.S. 1997. In situ stress from breakouts in the Danish Sector of the North Sea. Marine and Petroleum Geology, 14, 231-243.

Bachu, S., Bonijoly, D., Bradshaw, J., Burruss, R., Holloway, S., Christensen, N.P., Mathiassen, O.M. 2007. $\mathrm{CO}_{2}$ storage capacity estimation: methodology and gaps. International Journal of Greenhouse Gas Control, 1, 430-443.

Badley, M.E., Price, J.D., Backshall, L.C. 1989. Inversion, reactivated faults and related structures: seismic examples fromt eh southern North Sea. In: Cooper, M.A., Williams, G.D. (eds.) Inversion Tectonics. Geological Society, London, Special Publications, 44, 201-219.

Baptie, B. 2010. Seismogenesis and state of stress in the UK. Tectonophysics, 482, 150-159.

Barton, C.A., Zoback, M.D. 1994. Stress pertubations associated with active faults penetrated by boreholes: Possible evidence for near-complete stress drop and a new technique for stress magnitude measurements. Journal of Geophysical Research, 99, 9373-9390.

Becker, A., Blümling, P., Müller, W.H. 1987. Recent stress field and neotectonics in the Eastern Jura Mountains, Switzerland. Tectonophysics, 135, 277-288. 
Bell, J.S. 1990. Investigating stress regimes in sedimentary basins using information from oil industry wireline logs and drilling records. In: Hurst, A., Lovell, M.A., Morton, A.C. (eds.) Geological applications of wireline logs. Geological Society, London, Special Publications, 48, 305-325.

Bell, J.S. 1995. In situ stresses in sedimentary rocks (part 1): measurement techniques. Geoscience Canada, 23, (2), 85-99.

Besly, B. 1998. Carboniferous. In: Glennie, K.W. (Ed.) Petroleum Geology of the North Sea: Basic Concepts and Recent Advances. Blackwell Science, Oxford, 104-136.

Brudy, M., Kjørholt, H. 2001. Stress orientation on the Norwegian continental shelf derived from borehole failures observed in high-resolution borehole imaging logs. Tectonophysics, 337, 65-84.

Brudy, M., Zoback, M.D. 1999. Drilling-induced tensile wall-fractures: implications for the determination of in situ stress orientation and magnitude. International Journal of Rock Mechanics and Mining Sciences, 136, 191-215.

Cameron, T.D.J., Crosby, A., Balson, P.S., Jeffery, D.H., Lott, G.K., Bulat, J., Harrison, D.J. 1992. The Geology of the Southern North Sea. United Kingdom Offshore Regional Report. British Geological Survey and HMSO, London.

Cowgill, S.M., Meredith, P.G., Murrell, S.A.F., Brereton, N.R. 1993. Crustal Stresses in the North Sea from Breakouts and other Borehole Data. International Journal of Rock Mechanics and Mining Sciences \& Geomechanics Abstracts, 30, (7), 1111-1114.

Cuss, R.J., Rutter, E.H., Holloway, R.F. 2003. Experimental observations of the mechanics of borehole failure in porous sandstone. International Journal of Rock Mechanics \& Mining Sciences, 40, 747761.

Doornenbal, H., Stevenson, A. (eds) 2010. Petroleum Geological Atlas of the Southern Permian Basin Area. Houten, Netherlands, EAGE. 
Evans, C.J., Brereton, N.R. 1990. In situ crustal stress in the United Kingdom from borehole breakouts. In: Hurst, A., Lovell, M.A., Morton, A.C. (eds.) Geological applications of wireline logs. Geological Society, London, Special Publications, 48, 327-338.

Fejerskov, M., Lindholm, C. 2000. Crustal stress in and around Norway: an evaluation of stressgenerating mechanisms. In: Nottvedt, A. (Ed.) Dynamics of the Norwegian Margin. Geological Society, London, Special Publications, 167, 451-467.

Finkbeiner, T., Zoback, M., Flemings, P., Stump, B. 2001. Stress, pore pressure, and dynamically constrained hydrocarbon columns in the South Eugene Island 330 Field, northern Gulf of Mexico. AAPG Bulletin, 85, (6), 1007-1031.

Gölke, M., Brudy, M. 1996. Orientation of crustal stresses in the North Sea and Barents Sea inferred from borehole breakouts. Tectonophysics, 266, 25-32.

Gölke, M., Coblentz, D. 1996. Origins of the European regional stress field. Tectonophysics, 266, 1124.

Griffiths, P.A., Allen, M.R., Craig, J., Fitches, W.R., Whittington, R.J. 1995. Distinction between fault and salt control of Mesozoic sedimentation on the southern margin of the Mid-North Sea High. In: Boldy, S.A.R. (Ed.) Permian and Triassic Rifting in Northwest Europe. Geological Society, London, Special Publications, 91, 145-149.

Grollimund, B., Zoback, M.D., Wiprut, D.J., Arnesen, L. 2001. Stress orientation, pore pressure and least principal stress in the Norwegian sector of the North Sea. Petroleum Geoscience, 7, 173-180.

Havard, J., French, R. 2009. The importance of gas storage to the UK: The DECC perspective. In: Evans, D.J., Chadwick, R.A. (eds.) Underground Gas Storage: Worldwide Experiences and Future Development in the UK and Europe. Geological Society, London, Special publications, 313, 13-15. 
Heidbach, O., Tingay, M., Barth, A., Reinecker, J., Kurfeß, D., Müller, B. 2008. The World Stress Map database release 2008 doi:10.1594/GFZ.WSM.Rel2008.

Heidbach, O., Tingay, M., Barth, A., Reinecker, J., Kurfeß, D., Müller, B. 2010. Global crustal stress pattern based on the World Stress Map database release 2008. Tectonophysics, 482, (1-4), 3-15.

Hennings, P., Allwardt, P., Paul, P., Zahm, C., Reid Jr, R., Alley, H., Kirschner, R., Lee, B., Hough, E. 2012. Relationship between fractures, fault zones, stress, and reservoir productivity in the Suban gas field, Sumatra, Indonesia. AAPG Bulletin, 96, (4), 753-772.

Hillis, R.R., Nelson, E.J. 2005. In situ stresses in the North Sea and their applications: petroleum geomechanics from exploration to development. In: Dóre, A.G., Vining, B.A. (eds.) Petroleum Geology: North-West Europe and Global Perspectives - Proceedings of the $6^{\text {th }}$ Petroleum Geology Conference, Geological Society, London, 551-564.

Holloway, S., Vincent, C.J., Bentham, M.S., Kirk, K.L. 2006. Top-down and bottom-up estimates of $\mathrm{CO}_{2}$ storage capacity in the UK sector of the Southern North Sea Basin. Environmental Geoscience, $13,(2), 74-81$.

Klein, R.J., Barr, M.V. 1986. Regional state of stress in Western Europe. In: Stephansson, O. (Ed.) Proceedings of the International Symposium on Rock Stress and Rock Stress Measurements, Stockholm, 1-3 September 1986. Centek, Lulea, 33-44.

Mardia, K.V. 1972. Statistics of Directional Data: Probability and Mathematical Statistics. Academic Press, San Diego. 357 pp.

Mastin, L. 1988. Effect of borehole deviation on breakout orientations. Journal of Geophysical Research, 93, 9187-9195. 
Maury, V.M.R., Grasso, J.R., Wittlinger, G. 1992. Monitoring of Subsidence and Induced Seismicity in the Lacq Gas Field (France): The Consequences on Gas Production and Field Operation. Engineering Geology, 32, 123-135.

Moos, D., Zoback, M.D. 1990. Utilization of Observations of Well Bore Failure to Constrain the Orientation and Magnitude of Crustal Stresses: Application to Continental Deep Sea Drilling Project and Ocean Drilling Program Boreholes. Journal of Geophysical Research, 95, 9305-9325.

Müller, B., Wehrle, V., Hettel, S., Sperner, B., Fuchs, F. 2003. A new method for smoothing oriented data and its application to stress data. In: Ameen, M. (Ed.) Fracture and In-Situ Stress Characterization of Hydrocarbon Reservoirs. Geological Society, London, Special Publications, 209, $107-126$.

NETL 2008. Carbon Sequestration Atlas of the United States and Canada, $2^{\text {nd }}$ edition. U.S. Department of Energy, Office of Fossil Energy, National Energy Technology Laboratory.

Noy, D.J., Holloway, S., Chadwick, R.A., Williams, J.D.O., Hannis, S.D., Lahann, R.W. 2012. Modelling large-scale carbon dioxide injection into the Bunter Sandstone in the UK Southern North Sea. International Journal of Greenhouse Gas Control, 9, 220-233.

Plumb, R.A., Hickman, S.H. 1985. Stress-induced borehole enlargement: a comparison between the four-arm dipmeter and the borehole televiewer in the Auburn geothermal well. Journal of Geophysical Research, 90, 5513-5521.

Reynolds, S., Hillis, R., Paraschivoiu, E. 2003. In situ stress field, fault reactivation and seal integrity in the Bight Basin, South Australia. Exploration Geophysics, 34, 174-181.

Sperner, B., Müller, B., Heidbach, O, Delvaux, D., Reinecker, J., Fuchs, K. 2003. Tectonic Stress in the Earth's Crust: Advances in the World Stress Map Project. In: Nieuwland, D. (Ed.) New Insights into 
Structural Interpretation and Modelling. Geological Society, London, Special Publications, 212, 101116.

Stewart, S.A., Coward, M.P. 1995. Synthesis of slat tectonics in the southern North Sea, UK. Marine and Petroleum Geology, 12, (5), 457-475.

Streit, J.E., Hillis, R.R. 2004. Estimating fault stability and sustainable fluid pressures for underground storage of $\mathrm{CO}_{2}$ in porous rock. Energy, 29, 1445-1456.

Taylor, J.C.M. 1984. Late Permian -Zechstein. In: Glennie, K.W. (Ed.) Introduction to the Petroleum Geology of the North Sea. Blackwell Scientific Publications, Oxford, 87-111.

Teufel, L.W. 1991. Influence of lithology and geologic structure on in situ stress: Examples of stress heterogeneity in reservoirs. In: Lake, L.W., Carroll, H.B., Wesson, T.C. (eds.) Reservoir Characterization II. Academic Press, San Diego, 565-579.

Tingay, M., Bentham, P., De Feyter, A., Kellner, A., 2011. Present-day stress-field rotations associated with evaporites in the offshore Nile Delta. GSA Bulletin, 123, (5/6) 1171-1180.

Underhill, J.R. 2003. The tectonic and stratigraphic framework of the United Kingdom's oil and gas fields. In: Gluyas, J.G., Hichens, H.M. (eds.) United Kingdom Oil and Gas Fields, Commemorative Millennium Volume, Geological Society, London, Memoir 20, 17-59.

Underhill, J.R. 2009. Role of intrusion-induced salt mobility in controlling the formation of the enigmatic 'Silverpit Crater', UK Southern North Sea. Petroleum Geoscience, 15, 197-216.

Verdon, J.P., Kendall, J.M., Stork, A.L., Chadwick, R.A., White, D.J., Bissell, R.C. 2013. Comparison of geomechanical deformation induced by megatonne-scale $\mathrm{CO}_{2}$ storage at Sleipner, Weyburn, and In Salah. Proceedings of the National Academy of Sciences of the United States of America, 110, (30), E2762-E2771. 
Wall, M., Cartwright, J., Davies, R., McGrandle, A. 2009. 3D seismic imaging of a Tertiary Dyke Swarm in the Southern North Sea, UK. Basin Research, 22, (2), 181-194.

Williams, J.D.O., Holloway, S., Williams, G.A. 2014. Pressure constraints on the $\mathrm{CO}_{2}$ storage capacity of the saline water-bearing parts of the Bunter Sandstone Formation in the UK Southern North Sea. Petroleum Geoscience, 20, 155-167.

Withjack, M.O., Scheiner, C. 1982. Fault Patterns Associated with Domes - An Experimental and Analytical Study. AAPG Bulletin, 66, (3), 302-316.

Yale, D.P. 2003. Fault and stress magnitude controls on variations in the orientation of in situ stress. In: Ameen, M. (Ed.) Fracture and In-situ Stress Characterization of Hydrocarbon Reservoirs, Geological Society, London, Special Publications, 209, 55-64.

Yamada, Y., Okamura, H., Tamura, Y., Tsuneyama, F. 2005. Analog Models of Faults Associated with Salt Doming and Wrenching: Application to offshore United Arab Emirates. In: Sorkhabi, R., Tsuji, Y. (eds.) Faults, fluid flow, and petroleum traps. AAPG Memoir, 85, 95-106.

Yassir, N.A., Zerwer, A. 1997. Stress Regimes in the Gulf Coast, Offshore Louisiana: Data from WellBore Breakout Analysis. AAPG Bulletin, 81, (2), 293-307.

Yielding, G., Lykakis, N., Underhill, J.R. 2011. The role of stratigraphic juxtaposition for seal integrity in proven $\mathrm{CO}_{2}$ fault-bound traps of the Southern North Sea. Petroleum Geoscience, 17, 193-203.

Zoback, M.D., Moos, L.G., Mastin, L.G., Anderson, R.N. 1985. Well bore breakouts and in situ stress. Journal of Geophysical Research, 90, 5523-5530.

Zoback, M.D., Zinke, J.C. 2002. Production-induced Normal Faulting in the Valhall and Ekofisk Oil Fields. Pure and Applied Geophysics, 159, 403-420. 
Zoback, M.D., Barton, C.A., Brudy, M., Castillo, D.A., Finkbeiner, T., Grollimund, B.R., Moos, D.B., Peska, P., Ward, C.D., Wiprut, D.J. 2003. Determination of stress orientation and magnitude in deep wells. International Journal of Rock Mechanics \& Mining Sciences, 40, 1049-1076.

Zoback, M.D., Gorelick, S.M. 2012. Earthquake triggering and large-scale geologic storage of carbon dioxide. Proceedings of the National Academy of Sciences of the United States of America, 109, (26), 10164-10168. 
Appendix A Summary of $S_{H \max }$ orientation data derived on a per-well basis from borehole breakouts derived from analysis four-arm caliper logs.

\begin{tabular}{|c|c|c|c|c|c|c|c|}
\hline Well Name & $\begin{array}{l}\text { Minimum } \\
\text { Z (TVDSS) }\end{array}$ & $\begin{array}{l}\text { Maximum } \\
\mathrm{Z} \text { (TVDSS) }\end{array}$ & $\begin{array}{l}\text { Number of } \\
\text { Breakouts }\end{array}$ & $\begin{array}{c}\text { Total } \\
\text { Length } \\
\text { (m) }\end{array}$ & $\begin{array}{c}\mathrm{S}_{\mathrm{HMAX}} \\
\text { Azimuth }\left({ }^{\circ} \mathrm{N}\right)\end{array}$ & $\begin{array}{c}\text { Standard } \\
\text { Deviation } \\
\left(^{\circ}\right)\end{array}$ & $\begin{array}{c}\text { Quality } \\
\text { Rank }\end{array}$ \\
\hline 41/15-1 & 3140.6 & 3390.1 & 35 & 53.8 & 177 & 13.0 & C \\
\hline $42 / 10 a-1$ & 2697.3 & 2717.4 & 4 & 2.1 & 170 & 13.0 & D \\
\hline $42 / 10 b-2$ & 2524.6 & 2527.1 & 1 & 2.4 & 155 & 3.0 & $\mathrm{D}$ \\
\hline $42 / 13-2$ & 1938.1 & 2105.3 & 13 & 8.1 & 150 & 20 & D \\
\hline $42 / 27 a-1$ & 2866.3 & 3124.7 & 6 & 4.0 & 155 & 13 & $\mathrm{D}$ \\
\hline $42 / 28 b-7$ & 2568.8 & 2692.0 & 5 & 13.3 & 142 & 10 & D \\
\hline $42 / 29-2$ & 2877.6 & 2935.6 & 12 & 27.0 & 165 & 6 & D \\
\hline $42 / 29-3$ & 3071.5 & 3113.4 & 10 & 22.6 & 124 & 12 & $\mathrm{D}$ \\
\hline $42 / 29-5$ & 3166.3 & 3198.4 & 7 & 10.6 & 148 & 12 & D \\
\hline $42 / 30-2$ & 2984.7 & 2985.8 & 1 & 1.2 & 10 & 3 & $\mathrm{D}$ \\
\hline $42 / 30-4$ & 3147.2 & 3790.6 & 54 & 360.4 & 157 & 10 & A \\
\hline $43 / 12-1$ & 589.3 & 3437.5 & 57 & 159.6 & 89 & 27 & D \\
\hline $43 / 20 b-2$ & 3883.9 & 4317.8 & 2 & 1.0 & 160 & 5 & $E$ \\
\hline $43 / 21-2$ & 2851.4 & 4513.9 & 39 & 54.4 & 162 & 27 & $\mathrm{D}$ \\
\hline $43 / 23-1$ & 3340.2 & 3687.2 & 11 & 14.0 & 143 & 44 & $E$ \\
\hline $43 / 24-3$ & 3348.54 & 3416.14 & 11 & 46.8 & 180 & 16 & $C$ \\
\hline $43 / 27-J 2$ & 3264.3 & 3275.8 & 2 & 0.9 & 161 & 7 & $E$ \\
\hline $43 / 28 a-3$ & 3594.8 & 3674.1 & 3 & 2.4 & 155 & 32 & $E$ \\
\hline $44 / 12 a-3$ & 3662.4 & 3663.1 & 1 & 0.8 & 22 & 1 & $E$ \\
\hline $44 / 13-1$ & 990.1 & 1984.9 & 4 & 3.0 & 93 & 5 & D \\
\hline $44 / 14-2$ & 3497.9 & 3499.4 & 1 & 1.4 & 163 & 0.4 & $\mathrm{D}$ \\
\hline $44 / 16-3$ & 3894.3 & 3895.1 & 1 & 0.8 & 174 & 3 & $E$ \\
\hline $44 / 18 a-5$ & 3693.3 & 3770.2 & 6 & 5.9 & 144 & 9 & $\mathrm{D}$ \\
\hline $44 / 21-2$ & 4171.0 & 4495.1 & 19 & 36.4 & 147 & 10 & $C$ \\
\hline $44 / 21 b-11$ & 3558.1 & 3922.8 & 11 & 50.0 & 24 & 27 & D \\
\hline
\end{tabular}




\begin{tabular}{|c|c|c|c|c|c|c|c|}
\hline $44 / 22-1$ & 1713.9 & 1765.2 & 5 & 2.6 & 116 & 19 & $\mathrm{D}$ \\
\hline $44 / 22-7$ & 3972.2 & 3975.8 & 1 & 3.7 & 39 & 8 & $D$ \\
\hline $44 / 26-4$ & 3697.7 & 3770.5 & 21 & 37.5 & 146 & 11 & $C$ \\
\hline $44 / 28-2$ & 3926.1 & 4357.0 & 36 & 89.4 & 133 & 10 & $C$ \\
\hline $44 / 28-3$ & 3461.3 & 3562.6 & 18 & 20.6 & 32 & 14 & $D$ \\
\hline $44 / 28-4$ & 4036.7 & 4272.3 & 4 & 4.1 & 128 & 9 & $\mathrm{D}$ \\
\hline $44 / 29 b-4$ & 3315.0 & 3316.2 & 1 & 1.3 & 126 & 1 & $\mathrm{D}$ \\
\hline $47 / 02-1$ & 2960.0 & 3013.5 & 4 & 26.2 & 147 & 9 & D \\
\hline $47 / 03-1$ & 3118.7 & 3150.7 & 3 & 5.2 & 139 & 17 & $\mathrm{D}$ \\
\hline $47 / 03 e-9$ & 3220.9 & 3351.8 & 4 & 4.7 & 156 & 1 & $\mathrm{D}$ \\
\hline $47 / 05 a-3$ & 2832.7 & 3044.8 & 18 & 28.5 & 147 & 7 & $D$ \\
\hline $47 / 09 b-4$ & 1529.357 & 3145.757 & 70 & 226.4 & 160 & 33 & D \\
\hline $47 / 09 b-5 A$ & 2799.2 & 2887.7 & 5 & 15.3 & 179 & 9 & D \\
\hline $47 / 10-1$ & 2815.3 & 2877.2 & 7 & 41.3 & 138 & 12 & C \\
\hline $47 / 10-5$ & 733.4 & 1429.1 & 66 & 222.4 & 146 & 11 & $B$ \\
\hline $47 / 14 a-5$ & 1316.6 & 1389.6 & 10 & 13.5 & 175 & 14 & D \\
\hline $47 / 14 a-8$ & 2780.1 & 2781.8 & 2 & 1.4 & 161 & 3 & D \\
\hline $47 / 14 a-9$ & 2759.0 & 2798.5 & 8 & 6.7 & 165 & 6 & $\mathrm{D}$ \\
\hline $48 / 02 b-3$ & 3309.1 & 3355.8 & 7 & 37.5 & 39 & 11 & $C$ \\
\hline $48 / 06-26$ & 2798.3 & 3003.7 & 14 & 47.0 & 150 & 10 & C \\
\hline $48 / 06-28$ & 2994.2 & 3244.3 & 48 & 140.5 & 140 & 7 & B \\
\hline $48 / 07 a-9$ & 3031.1 & 3078.0 & 9 & 27.7 & 143 & 15 & $\mathrm{D}$ \\
\hline $48 / 10 b-4$ & 4241.6 & 4620.6 & 18 & 55.2 & 141 & 6 & $C$ \\
\hline $48 / 10 b-5$ & 3694.4 & 3825.3 & 9 & 9.4 & 149 & 7 & $\mathrm{D}$ \\
\hline 48/11a-12 & 3004.3 & 3083.3 & 9 & 52.4 & 124 & 14 & $C$ \\
\hline $48 / 13 a-5$ & 2531.9 & 2596.3 & 11 & 47.7 & 143 & 9 & $C$ \\
\hline $48 / 19 b-9$ & 455.5 & 1565.2 & 37 & 61.7 & 135 & 27 & $\mathrm{D}$ \\
\hline $48 / 24 a-3$ & 2513.3 & 2910.7 & 5 & 8.5 & 166 & 16 & $\mathrm{D}$ \\
\hline $49 / 01-3$ & 3925.9 & 4423.0 & 4 & 3.0 & 148 & 18 & $\mathrm{D}$ \\
\hline $49 / 02 a-5 z$ & 3871.3 & 3872.3 & 1 & 1.1 & 140 & 2 & $\mathrm{D}$ \\
\hline $49 / 10 b-3$ & 3672.0 & 3673.9 & 1 & 2.0 & 123 & 11 & $\mathrm{D}$ \\
\hline
\end{tabular}




\begin{tabular}{|l|l|l|l|l|l|l|l|}
\hline $49 / 14 b-4$ & 3462.1 & 3463.9 & 1 & 1.9 & 145 & 26 & D \\
\hline $49 / 15 a-2$ & 3209.2 & 3214.0 & 1 & 4.9 & 158 & 5 & D \\
\hline $49 / 16-6$ & 803.1 & 3266.0 & 135 & 318.6 & 161 & 48 & E \\
\hline $49 / 25 a-4$ & 2474.7 & 2480.9 & 2 & 4.9 & 126 & 6 & D \\
\hline $49 / 25 a-9$ & 1486.3 & 1507.4 & 5 & 6.6 & 45 & 6 & D \\
\hline $49 / 26-27$ & 860.4 & 1397.8 & 9 & 36.6 & 133 & 7 & C \\
\hline $49 / 28-12$ & 2525.293 & 2563.893 & 16 & 14.0 & 149 & 5 & $D$ \\
\hline $49 / 30 b-4$ & 2023.3 & 2036.7 & 5 & 11.5 & 128 & 6 & D \\
\hline $50 / 26 a-7$ & 2184.3 & 2184.8 & 1 & 0.6 & 107 & 1 & E \\
\hline $52 / 05 b-12$ & 1491.8 & 1968.9 & 12 & 14.5 & 139 & 9 & D \\
\hline $53 / 01 a-13$ & 1590.0 & 1675.9 & 15 & 22.0 & 138 & 9 & D \\
\hline $53 / 02-4$ & 1555.5 & 1680.6 & 9 & 52.1 & 88 & 14 & C \\
\hline
\end{tabular}


Appendix B Summary of $S_{H \max }$ orientation data derived stratigraphically on a per-well basis from borehole breakouts derived from analysis four-arm caliper logs.

\begin{tabular}{|c|c|c|c|c|c|c|c|c|}
\hline $\begin{array}{l}\text { Well } \\
\text { Name }\end{array}$ & $\begin{array}{l}\text { Stratig- } \\
\text { raphy }\end{array}$ & $\begin{array}{c}\text { Minimum Z } \\
\text { (TVDSS) }\end{array}$ & $\begin{array}{c}\text { Maximum Z } \\
\text { (TVDSS) }\end{array}$ & $\begin{array}{l}\text { Number of } \\
\text { Breakouts }\end{array}$ & $\begin{array}{l}\text { Total } \\
\text { Length } \\
\text { (m) }\end{array}$ & $\begin{array}{c}\mathrm{S}_{\mathrm{HMAX}} \\
\text { Azimuth } \\
\left({ }^{\circ} \mathrm{N}\right)\end{array}$ & $\begin{array}{c}\text { Standard } \\
\text { Deviation } \\
\left(^{\circ}\right)\end{array}$ & $\begin{array}{c}\text { Quality } \\
\text { Rank }\end{array}$ \\
\hline $41 / 15-1$ & CARB & 3140.6 & 3390.1 & 35 & 53.8 & 177 & 13.0 & C \\
\hline $42 / 10 a-1$ & CARB & 2697.3 & 2717.4 & 4 & 2.1 & 170 & 13.0 & $\mathrm{D}$ \\
\hline $42 / 10 b-2$ & CARB & 2524.6 & 2527.1 & 1 & 2.4 & 155 & 3.0 & $\mathrm{D}$ \\
\hline $42 / 13-2$ & ZECH & 1938.1 & 2105.3 & 13 & 8.1 & 150 & 20 & $\mathrm{D}$ \\
\hline $42 / 27 a-1$ & CARB & 3008.7 & 3124.7 & 4 & 2.6 & 160 & 10 & $\mathrm{D}$ \\
\hline $42 / 27 a-1$ & $\mathrm{ZECH}$ & 2866.3 & 2868.3 & 2 & 1.4 & 144 & 10 & D \\
\hline $42 / 28 b-7$ & CARB & 2568.8 & 2692.0 & 5 & 13.3 & 142 & 10 & $\mathrm{D}$ \\
\hline $42 / 29-2$ & CARB & 2877.6 & 2935.6 & 12 & 27 & 165 & 6 & $\mathrm{D}$ \\
\hline $42 / 29-3$ & ROTL & 3071.5 & 3113.4 & 10 & 22.6 & 124 & 12 & $\mathrm{D}$ \\
\hline $42 / 29-5$ & CARB & 3166.3 & 3198.4 & 7 & 10.6 & 148 & 12 & $\mathrm{D}$ \\
\hline $42 / 30-2$ & ROTL & 2984.7 & 2985.8 & 1 & 1.3 & 10 & 3 & D \\
\hline $42 / 30-4$ & CARB & 3147.2 & 3790.6 & 54 & 360.4 & 157 & 10 & A \\
\hline $43 / 12-1$ & CARB & 3387.1 & 3437.5 & 4 & 2.2 & 160 & 6 & $\mathrm{D}$ \\
\hline $43 / 12-1$ & JURTRI & 589.3 & 1203.6 & 52 & 156.5 & 87 & 26 & $\mathrm{D}$ \\
\hline $43 / 12-1$ & ROTL & 3304.8 & 3305.6 & 1 & 0.9 & 152 & 2 & $E$ \\
\hline $43 / 20 b-2$ & CARB & 3883.9 & 4317.8 & 2 & 1 & 160 & 5 & $E$ \\
\hline $43 / 21-2$ & CARB & 3097.0 & 4513.9 & 32 & 34.3 & 153 & 22 & C \\
\hline $43 / 21-2$ & ROTL & 2889.6 & 3096.9 & 4 & 5.6 & 143 & 44 & $E$ \\
\hline $43 / 21-2$ & $\mathrm{ZECH}$ & 2851.4 & 2868.8 & 3 & 14.5 & 177 & 11 & $\mathrm{D}$ \\
\hline $43 / 23-1$ & CARB & 3340.2 & 3687.2 & 11 & 14 & 143 & 44 & $E$ \\
\hline $43 / 24-3$ & ROTL & 3348.54 & 3416.14 & 11 & 46.8 & 180 & 16 & $\mathrm{C}$ \\
\hline $43 / 27-J 2$ & ROTL & 3264.3 & 3275.8 & 2 & 0.9 & 161 & 7 & $\mathrm{E}$ \\
\hline $43 / 28 a-3$ & CARB & 3594.8 & 3674.1 & 3 & 2.4 & 155 & 32 & D \\
\hline $44 / 12 a-3$ & CARB & 3662.4 & 3663.1 & 1 & 0.8 & 22 & 1 & $E$ \\
\hline $44 / 13-1$ & JURTRI & 1984.3 & 1984.9 & 1 & 0.7 & 93 & 1 & $E$ \\
\hline
\end{tabular}




\begin{tabular}{|c|c|c|c|c|c|c|c|c|}
\hline $44 / 13-1$ & TERT & 990.1 & 1001.3 & 3 & 2.3 & 94 & 4 & D \\
\hline $44 / 14-2$ & CARB & 3497.9 & 3499.4 & 1 & 1.4 & 163 & 0.4 & D \\
\hline $44 / 16-3$ & CARB & 3894.3 & 3895.1 & 1 & 0.8 & 174 & 3 & $E$ \\
\hline $44 / 18 a-5$ & CARB & 3693.3 & 3770.2 & 6 & 5.9 & 144 & 9 & $\mathrm{D}$ \\
\hline $44 / 21-2$ & CARB & 4171.0 & 4495.1 & 19 & 36.4 & 147 & 10 & C \\
\hline $\begin{array}{l}44 / 21 b- \\
11\end{array}$ & CARB & 3922.4 & 3922.8 & 1 & 0.5 & 118 & 2 & $E$ \\
\hline $\begin{array}{l}44 / 21 b- \\
11\end{array}$ & ROTL & 3558.1 & 3651.2 & 10 & 49.5 & 25 & 26 & $D$ \\
\hline $44 / 22-1$ & JURTRI & 1713.9 & 1765.2 & 5 & 2.6 & 116 & 19 & D \\
\hline $44 / 22-7$ & CARB & 3972.2 & 3975.8 & 1 & 3.7 & 39 & 8 & $D$ \\
\hline $44 / 26-4$ & ROTL & 3697.7 & 3770.5 & 21 & 37.5 & 146 & 11 & $\mathrm{C}$ \\
\hline $44 / 28-2$ & CARB & 3926.1 & 4357.0 & 36 & 89.4 & 133 & 10 & $C$ \\
\hline $44 / 28-3$ & ROTL & 3461.3 & 3562.6 & 18 & 20.6 & 32 & 14 & $D$ \\
\hline $44 / 28-4$ & CARB & 4036.7 & 4272.3 & 4 & 4.1 & 128 & 9 & $D$ \\
\hline $44 / 29 b-4$ & $\mathrm{ZECH}$ & 3315.0 & 3316.2 & 1 & 1.3 & 126 & 1 & $D$ \\
\hline $47 / 02-1$ & CARB & 2960.0 & 3013.5 & 4 & 26.2 & 147 & 9 & $D$ \\
\hline $47 / 03-1$ & $\mathrm{ZECH}$ & 3118.7 & 3150.7 & 3 & 5.2 & 139 & 17 & $D$ \\
\hline $47 / 03 e-9$ & CARB & 3220.9 & 3351.8 & 4 & 4.7 & 156 & 1 & $D$ \\
\hline $47 / 05 a-3$ & CARB & 3027.7 & 3044.8 & 5 & 6.1 & 154 & 7 & D \\
\hline $47 / 05 a-3$ & ROTL & 2832.7 & 2920.4 & 13 & 22.4 & 145 & 6 & $\mathrm{D}$ \\
\hline $47 / 09 b-4$ & CARB & 3090.457 & 3145.757 & 4 & 6.9 & 177 & 5 & $D$ \\
\hline $47 / 09 b-4$ & JURTRI & 1529.4 & 2601.3 & 39 & 147.7 & 160 & 43 & $E$ \\
\hline $47 / 09 b-4$ & ZECH & 2601.8 & 2952.4 & 27 & 71.8 & 158 & 12 & $C$ \\
\hline $\begin{array}{l}47 / 09 b- \\
5 A\end{array}$ & CARB & 2799.2 & 2887.7 & 5 & 15.3 & 179 & 9 & D \\
\hline $47 / 10-1$ & CARB & 2844.6 & 2877.2 & 5 & 24 & 143 & 11 & $D$ \\
\hline $47 / 10-1$ & ROTL & 2837.0 & 2844.3 & 1 & 7.3 & 126 & 9 & D \\
\hline $47 / 10-1$ & $\mathrm{ZECH}$ & 2815.3 & 2825.2 & 1 & 10 & 137 & 6 & D \\
\hline $47 / 10-5$ & CRET & 733.4 & 854.6 & 24 & 102.2 & 144 & 12 & B \\
\hline $47 / 10-5$ & JURTRI & 882.7 & 1429.1 & 42 & 120.2 & 148 & 10 & B \\
\hline
\end{tabular}




\begin{tabular}{|c|c|c|c|c|c|c|c|c|}
\hline $47 / 14 a-5$ & JURTRI & 1316.6 & 1389.6 & 10 & 13.5 & 175 & 14 & $D$ \\
\hline $47 / 14 a-8$ & CARB & 2780.1 & 2781.8 & 2 & 1.4 & 161 & 3 & D \\
\hline $47 / 14 a-9$ & CARB & 2789.1 & 2798.5 & 6 & 4.7 & 162 & 5 & D \\
\hline $47 / 14 a-9$ & ROTL & 2759.0 & 2761.1 & 2 & 2 & 172 & 4 & $D$ \\
\hline $48 / 02 b-3$ & CARB & 3309.1 & 3355.8 & 7 & 37.5 & 39 & 11 & C \\
\hline $48 / 06-26$ & CARB & 2973.3 & 3003.7 & 2 & 10.8 & 157 & 10 & D \\
\hline $48 / 06-26$ & ROTL & 2798.3 & 2935.8 & 12 & 36.2 & 148 & 9 & C \\
\hline $48 / 06-28$ & CARB & 3222.1 & 3244.3 & 2 & 1.8 & 163 & 6 & D \\
\hline $48 / 06-28$ & ROTL & 2994.2 & 3189.8 & 46 & 138.7 & 140 & 7 & B \\
\hline $48 / 07 a-9$ & CARB & 3057.7 & 3078.0 & 3 & 12.5 & 149 & 8 & D \\
\hline $48 / 07 a-9$ & ROTL & 3031.1 & 3057.2 & 6 & 15.2 & 138 & 18 & D \\
\hline $48 / 10 b-4$ & CARB & 4241.6 & 4620.6 & 18 & 55.2 & 141 & 6 & C \\
\hline $48 / 10 b-5$ & CARB & 3694.4 & 3825.3 & 9 & 9.4 & 149 & 7 & D \\
\hline $\begin{array}{l}48 / 11 a- \\
12\end{array}$ & ROTL & 3004.3 & 3083.3 & 9 & 52.4 & 124 & 14 & C \\
\hline $48 / 13 a-5$ & CARB & 2531.9 & 2596.3 & 11 & 47.7 & 143 & 9 & C \\
\hline $48 / 19 b-9$ & JURTRI & 455.5 & 1565.2 & 37 & 61.7 & 135 & 27 & $\mathrm{D}$ \\
\hline $48 / 24 a-3$ & CARB & 2513.3 & 2910.7 & 5 & 8.5 & 166 & 16 & D \\
\hline $49 / 01-3$ & CARB & 3925.9 & 4423.0 & 4 & 3 & 148 & 18 & D \\
\hline $\begin{array}{l}49 / 02 a- \\
5 z\end{array}$ & CARB & 3871.3 & 3872.3 & 1 & 1.1 & 140 & 2 & $D$ \\
\hline $49 / 10 b-3$ & CARB & 3672.0 & 3673.9 & 1 & 2 & 123 & 11 & D \\
\hline $49 / 14 b-4$ & CARB & 3462.1 & 3463.9 & 1 & 1.9 & 145 & 26 & D \\
\hline $49 / 15 a-2$ & ROTL & 3209.2 & 3214.0 & 1 & 4.9 & 158 & 5 & $D$ \\
\hline $49 / 16-6$ & CARB & 3020.2 & 3266.0 & 9 & 38.1 & 133 & 8 & C \\
\hline $49 / 16-6$ & JURTRI & 803.1 & 1784.8 & 121 & 273.7 & 173 & 48 & $\mathrm{E}$ \\
\hline $49 / 16-6$ & ROTL & 2821.3 & 2827.3 & 2 & 1.9 & 156 & 9 & D \\
\hline $49 / 16-6$ & ZECH & 2764.2 & 2771.2 & 3 & 4.9 & 50 & 8 & D \\
\hline $49 / 25 a-4$ & ZECH & 2474.7 & 2480.9 & 2 & 4.9 & 126 & 6 & $D$ \\
\hline $49 / 25 a-9$ & CRET & 1486.3 & 1507.4 & 5 & 6.6 & 45 & 6 & $\mathrm{D}$ \\
\hline $49 / 26-27$ & JURTRI & 860.4 & 1397.8 & 9 & 36.6 & 133 & 7 & C \\
\hline
\end{tabular}




\begin{tabular}{|c|c|c|c|c|c|c|c|c|}
\hline 49/28-12 & CARB & 2556.193 & 2563.893 & 4 & 3.9 & 154 & 4 & $\mathrm{D}$ \\
\hline 49/28-12 & ROTL & 2525.3 & 2544.7 & 12 & 10.1 & 148 & 4 & D \\
\hline $49 / 30 b-4$ & JURTRI & 2023.3 & 2036.7 & 5 & 11.5 & 128 & 6 & $\mathrm{D}$ \\
\hline $50 / 26 a-7$ & $\mathrm{ZECH}$ & 2184.3 & 2184.8 & 1 & 0.6 & 107 & 1 & $E$ \\
\hline $\begin{array}{l}52 / 05 b- \\
12\end{array}$ & CARB & 1949.4 & 1968.9 & 5 & 6.2 & 148 & 6 & $\mathrm{D}$ \\
\hline $\begin{array}{l}52 / 05 b- \\
12\end{array}$ & JURTRI & 1491.8 & 1583.7 & 7 & 8.3 & 133 & 4 & $\mathrm{D}$ \\
\hline $\begin{array}{l}53 / 01 a- \\
13\end{array}$ & JURTRI & 1590.0 & 1675.9 & 15 & 22 & 138 & 9 & $\mathrm{D}$ \\
\hline $53 / 02-4$ & JURTRI & 1555.5 & 1581.4 & 3 & 3.7 & 147 & 14 & D \\
\hline $53 / 02-4$ & $\mathrm{ZECH}$ & 1598.8 & 1680.6 & 6 & 48.4 & 87 & 5 & $C$ \\
\hline
\end{tabular}

